\title{
Long-run Supply and Demand Elasticities in the Spanish Housing Market
}

Authors

\author{
María Arrazola, José de Hevia, Desiderio \\ Romero-Jordán, and José Félix Sanz-Sanz
}

Abstract

In this paper, we analyze housing supply and demand in Spain. Using data for 1975 to 2009, reduced form and structural models are estimated. The results show that faced with situations of disequilibrium, prices adjust more rapidly than stocks. Similarly, they demonstrate that demand shows low sensitivity to variations in prices and real interest rates. By contrast, it is highly sensitive to demographic changes and the evolution of the labor market. The evidence confirms that permanent income has greater weight than prices as a determinant of demand. On the contrary, supply is highly sensitive to variations in prices and interest rates.

Between the mid-1990s and the onset of the Great Recession, the majority of real estate markets, in both developed and developing countries, suffered severe price increases (Girouard, Kennedy, Van den Noord, and André, 2006; André, 2010; Wang and Wang, 2012). In the European Union, the country most affected by the housing bubble has been Ireland, where real house prices almost tripled, followed by other countries like the United Kingdom and Spain, where they more than doubled. In the case of the two leading economies of the world, prices increased by up to $50 \%$ in the United States and between $169 \%$ to $431 \%$ in the ten largest Chinese cities (André, 2010; Wang, 2014). The recent international financial crisis put an end to this situation, generating sharp corrections in housing prices. For example, in Ireland and Spain, prices have been decreasing since the end of 2007 for 19 consecutive quarters, reaching falls of $50.1 \%$ and $32.0 \%$ respectively (Central Statistics Office, 2014; Instituto Nacional de Estadística, 2014).

Given the effects of bubbles upon the real economy, there are a number of researchers that study their origins, intensities, and effects for OECD or EU countries using panel data (e.g., Wigren and Wilhelmsson, 2007; Frappa and Mésonnier, 2010; Agnello and Schuknecht, 2011; Bracke, 2013; Caldera Sánchez and Johansson, 2013). Others analyze the property market of a specific country, especially in the case of the United States (e.g., Duca, Muellbauer, and Murphy, 2010; Barakova, Calem, and Wachter, 2014; Wang, 2014). Unfortunately, much less is known of countries such as Ireland, Spain or China, all deeply affected by recent episodes of property bubbles (Hay, 2009; Conefrey and Gerald, 2010; 
Wang, Chan, and Xu, 2012; García-Montalvo, 2013; Kang and Liu, 2014). Yet, as Wang and Wang (2012) state, it seems reasonable to probe more deeply into other experiences other than that of the U.S., of both developed and developing countries, since the real estate markets of each country have specific features deserving of analysis and understanding.

There are various arguments that justify analysis of the Spanish case. Firstly, as mentioned earlier, Spain led, together with the U.K. and Ireland, the rise in housing prices in the last property boom. Secondly, $40 \%$ of all dwellings constructed in the EU in the first decade of the twenty-first century were located in Spain (Sánchez-Martínez, 2008). ${ }^{1}$ However the Spanish population accounts for only $9 \%$ of that of the EU. Secondly, the impact of the puncture on the economy has been much more serious than in other developed countries because the volume of resources allocated to housing construction has been enormous. At the end of the 1990s, the weight of the residential investment sector in GDP was close to $9 \% .^{2}$ As a result, the ending of the bubble practically tripled the unemployment rate in Spain. ${ }^{3}$ Finally, the intensity of this crisis placed Spain on the edge of a rescue package by the EU (Moro, 2013; Gruppe and Lange, 2014). ${ }^{4}$ The application of a total rescue plan for Spain, similar to that employed earlier in the cases of Greece, Ireland, and Portugal, was unfeasible due to the size of its economy. Spain nevertheless received a rescue package from the EU to restructure the sharp deterioration in the balance sheets of financial institutions, due to their excessive exposure to the property bubble. As had happened in other countries such as the U.S., Spanish banks and savings banks had been extremely vulnerable to changes in the value of real estate, given the excessive weight of the property sector in the economy.

This study connects with the literature on the determinants of property booms, on both the supply and demand side. Our aim is to help to understand why the recent Spanish property cycle has been one of the most severe in the developed countries. Additionally, this paper offers estimations of the adjustment speed of the enormous real estate stock, which has existed since the bursting of the bubble in 2008 (Ministerio de Fomento, 2012a). The results confirm our intuition that the growth of residential investment is based on a greater sensitivity of demand to income than to prices. A similar pattern of behavior has been encountered in recent years in European countries such as Austria, Denmark, and Switzerland (Knudsen, 1994; Lee, Schmidt-Dengler, Felderer, and Helmenstein, 2001; Steiner, 2010). By contrast, for the U.S., Riddel (2004) found similar values in the price and income elasticities of demand. Despite this, we expected an income elasticity of demand of around unity, although the value obtained is close to 0.5 . One factor that may help us to understand this result is the strong preference of Spaniards for homeownership as against renting; 83.2\% of Spanish households own a property, whether as a habitual residence or as an investment good, compared to $81.2 \%$ in Ireland, $68.7 \%$ in the U.S., and 38.4\% in Switzerland (Andrews and Caldera Sánchez, 2011). This culture of ownership means that the Spanish economy is in the long run more vulnerable than those of other developed countries to deepseated property cycles. 
The paper continues as follows. In the following section, we offer an overview of the evolution of the Spanish housing stock in the last four decades and its determining factors. In Section 3, we review the evidence available regarding housing supply and demand elasticities. The theoretical framework is presented in Section 4. In Section 5, we describe the data. The results are presented in Sections 6 and 7. Concluding remarks are given in Section 8.

The Evolution of Housing Stock in Spain: Stylized Facts

In the last 30 years, two property booms have taken place in Spain. The first of these occurred between 1986 and 1991. At its peak, approximately 400,000 dwellings were built per year, doubling the figure at the beginning of that period, and prices increased by $69 \%$ (Naredo, 1996, 2004). The second boom, lasting 11 years, commenced in 1997 and came to an abrupt halt in 2007, following the international financial crisis originating with the collapse of the U.S. subprime mortgage market. In this latter boom, which coincided with the expansive property cycle in other OECD countries, construction peaks close to 700,000 dwellings per year were reached, causing housing prices to double (André, 2010; Agnello and Schuknecht, 2011). At the beginning of the 2000s, various studies warned that prices could be overvalued by between $20 \%$ and $50 \% .^{5}$ Unfortunately, corrective measures were not taken; laxity in the granting of mortgages and low interest rates did the rest.

As Exhibit 1 shows that in the last four decades, housing stock in Spain has multiplied by 2.6 in gross terms and has tripled in net terms. ${ }^{6}$ This trend is explained by the sharp increases in both the number of dwellings constructed and the evolution of housing prices. On the basis of the censuses undertaken at the beginning of each decade, we know that the number of dwellings in 1970 was 10.4 million, reaching 25.8 million in 2010 (Tafunell, 2005; Ministerio de Fomento, 2012b). ${ }^{7}$ One-third of this increase took place during the latest property boom (5.1 million units). The second of the factors referred to are prices. Exhibit 2 shows three stages in the growth of this variable in nominal terms: (1) 1975 to 1990, when prices increased in nominal terms at an annual average close to $4.7 \%$; (2) the first part of the 1990s, when this increase was $3.6 \%$ on average; and (3) the mid-1990s to 2008, when the annual variation was $8.8 \%$. However, when the evolution of housing prices is compared to the cost of living (Exhibit 2), measured by the Consumer Price Index (CPI), it can be seen that house prices increased by less than the cost of living until the mid-1990s.

The increase in stock and in real housing prices is the result of a strong simultaneous pressure by supply and demand factors. One of these factors is the increase in population. Exhibit 3 shows that the Spanish population grew strongly from the end of the 1990s, coinciding with the second of the property booms. Specifically, in 2007 there was an historic increase of 805,000 inhabitants. The Spanish population increased in the 1980s and the 1990s by approximately 1.2 and 1.1 million inhabitants respectively, while in the 2000 to 2008 period, the

\begin{tabular}{l|l|ll} 
JRER & Vol. 37 & $\mathrm{No} .3-2015$ \\
\hline
\end{tabular}


Arrazola, Hevia, Romero-Jordán, and Sanz-Sanz

Exhibit 1 | Real Value of Housing Stock

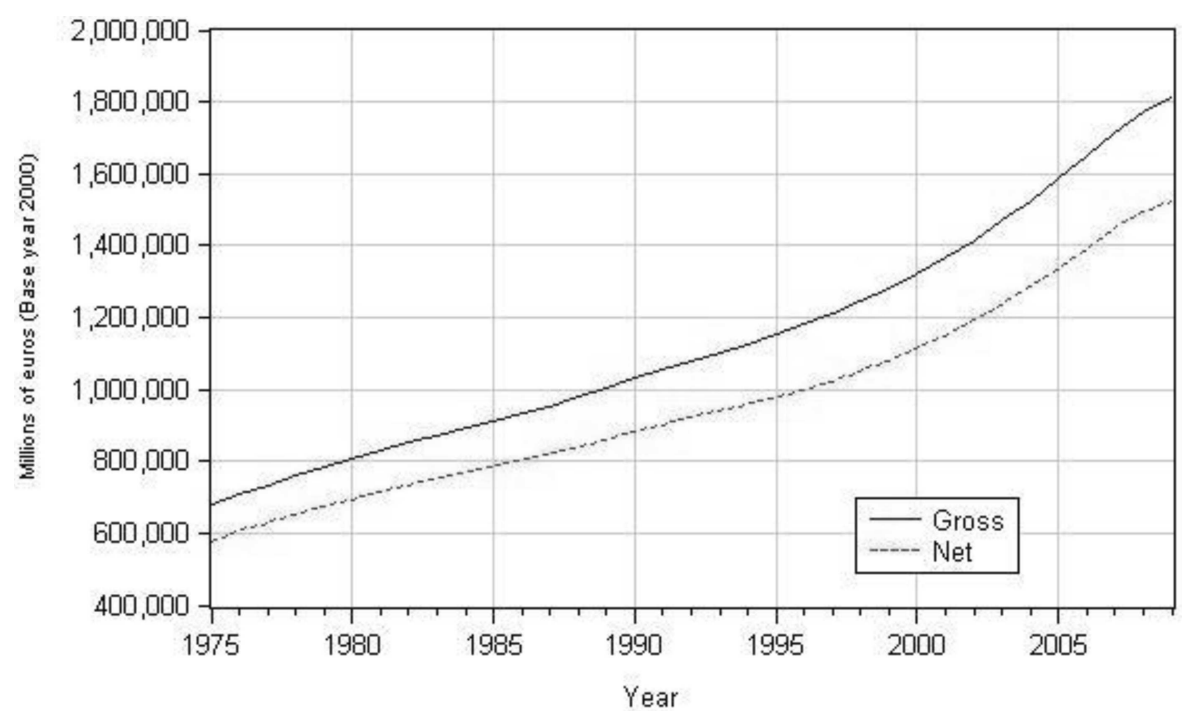

Exhibit 2 | Housing Prices

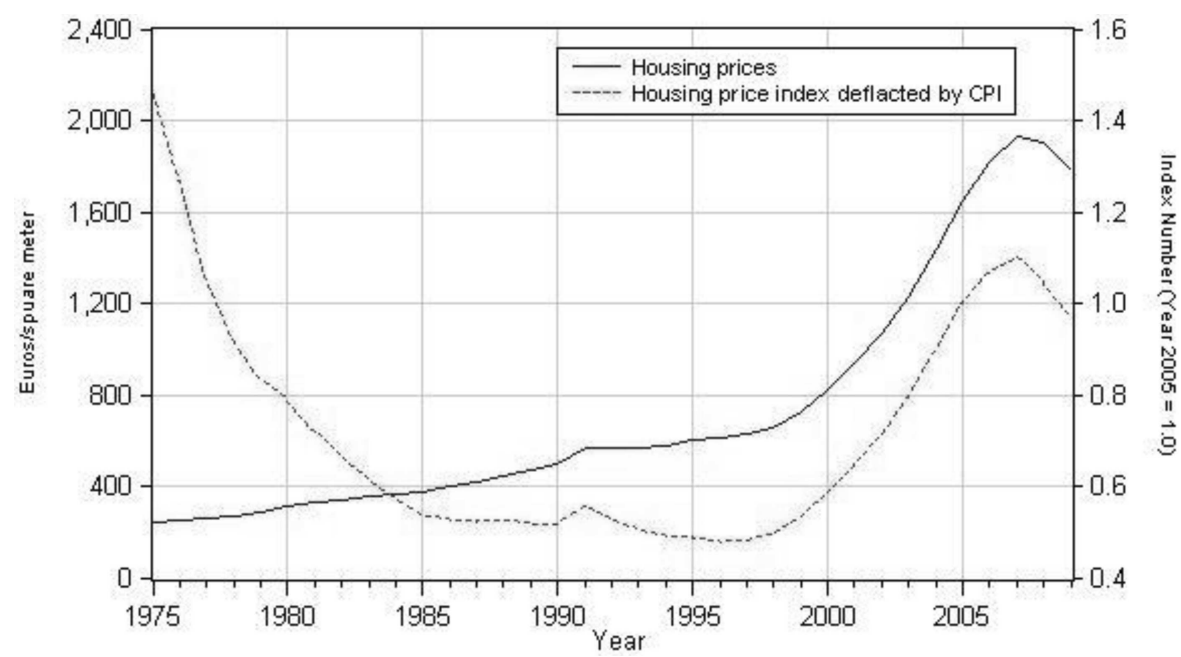


Exhibit 3 | Total Population

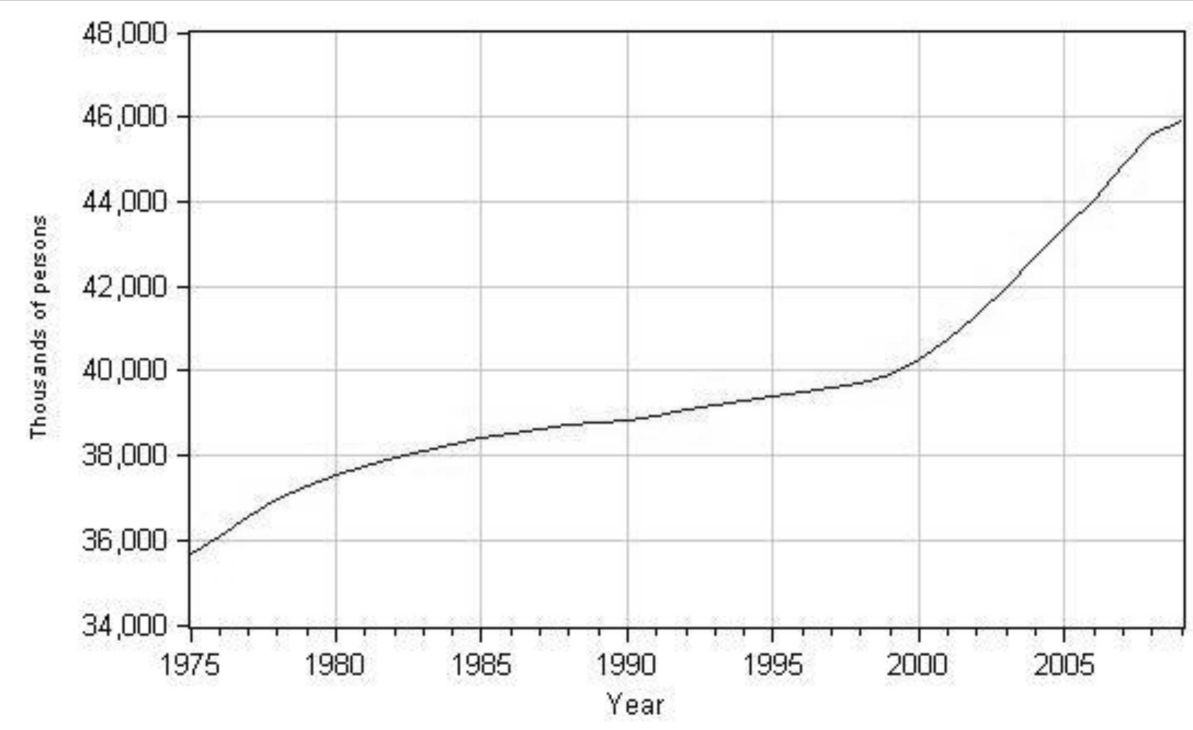

increase was 5.6 million inhabitants. Behind this sharp growth is, without a doubt, the increase in the immigrant population. The percentage of foreigners residing in Spain rose from $0.5 \%$ at the end of the 1970s to $12.2 \%$ in 2009. On this point, González and Ortega (2013) suggest that immigration was responsible for a quarter of price increases and half of the dwellings constructed during that period.

Another factor affecting housing stock in Spain has been the changes in the income level of Spanish households. As Exhibit 4 shows, since 1975 a constant increase in the per capita income of Spaniards has taken place, interrupted only by the recent financial crisis and that of the early 1990s. From the mid-1990s onwards, the increase in income per capita has been accompanied by a significant improvement in the labor market, as reflected in the evolution of the unemployment rate. As can be seen in Exhibit 5, in the first boom, the average unemployment rate was $18.4 \%$ and rose to $24 \%$ in 1994 after the housing bubble burst. In the second boom, the average was $12.3 \%$, although exceptionally low values for the Spanish economy were reached prior to the end of the bubble. The end of this second property boom elevated the unemployment rate to $18 \%$ in 2009 and to $26 \%$ in 2013.

With regard to the costs of housing financing, Exhibit 6 displays the evolution of mortgage interest rates in both nominal and real terms. As can be seen, nominal interest rates were maintained above 10\% between 1975 and 1993, reaching a 
Exhibit 4 | Gross Domestic Product Per Capita

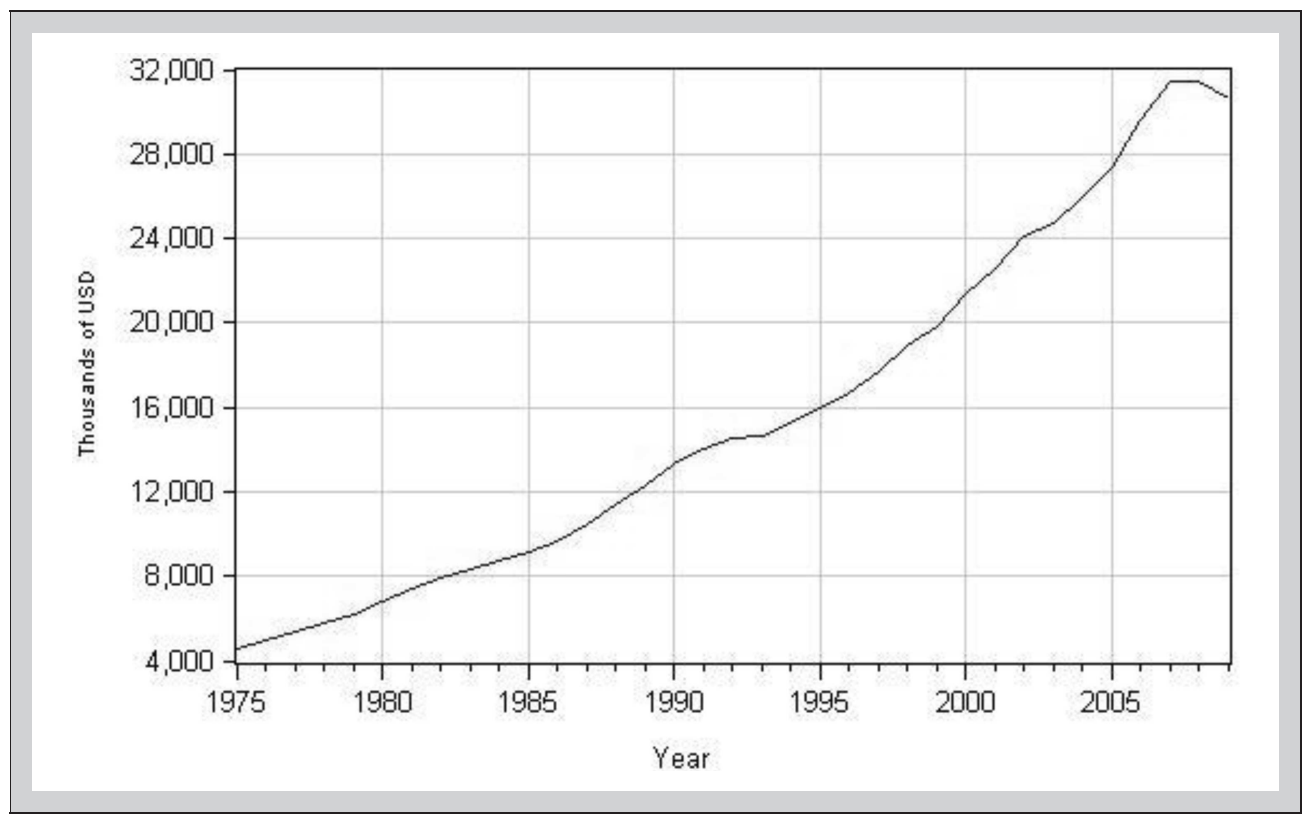

high point of $16.91 \%$ in 1982 . However, at the end of the 1990s a rapid and constant decrease began, with rates falling from $15.6 \%$ in 1990 to $3.2 \%$ in 1999 . In comparative terms, average nominal mortgage interest rates during the boom of the late 1980s were $13.7 \%$, while in the last boom these were $4.1 \%$. In the case of real rates, the averages were, respectively, $7.3 \%$ for the first boom and $1.2 \%$ for the second; real rates even became negative in 2005. It can be stated that Spain's entry into the European Monetary Union drastically reduced the cost of housing financing. At the same time, the policy of low interest rates adopted by the Central European Bank contributed to prolonging and strengthening the last property boom.

\section{Literature Review}

Exhibit 7 presents the long-term supply and demand elasticities of housing in developed countries. The results should be compared with caution, due to important differences in questions such as the periods analyzed or the methodological approach employed (Meen, 2002). Adopting this circumspection, a rapid review of the information given in Exhibit 7 reveals the existence of a high degree of dispersion in price and income elasticities on both the supply and demand sides, even within the same country. ${ }^{8}$ 


\section{Exhibit 5 | Unemployment Rate}

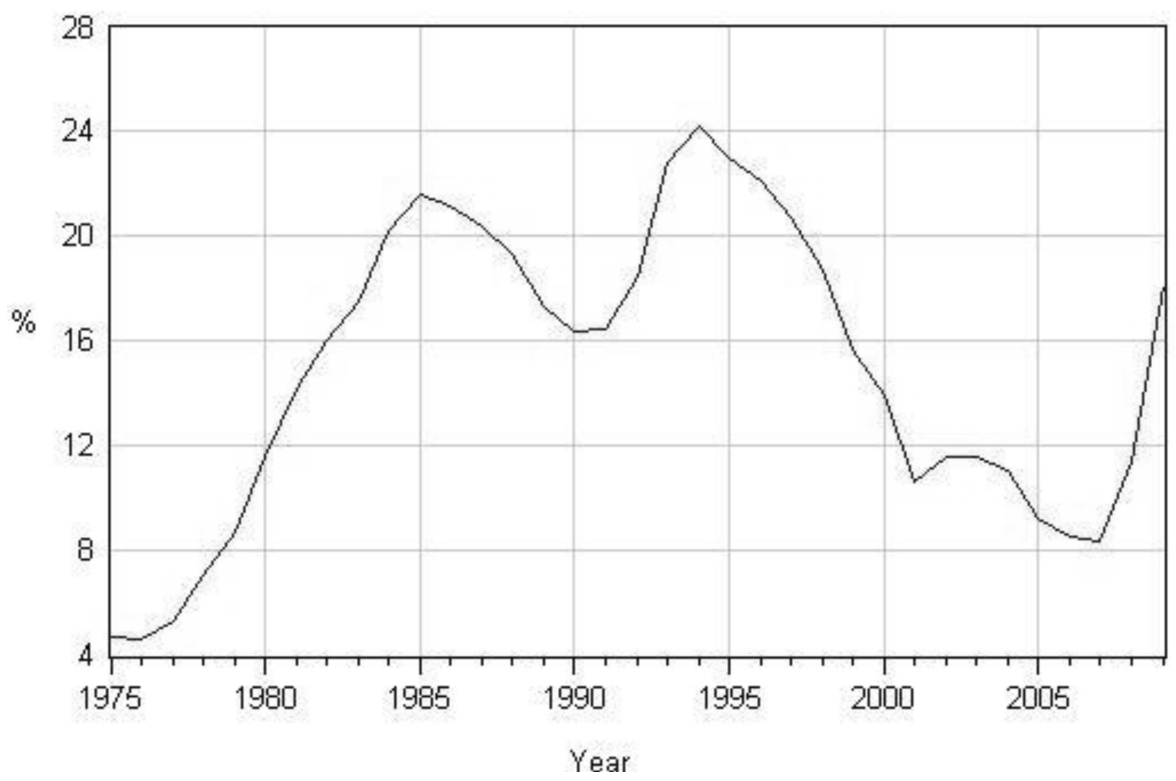

\section{Supply Elasticities}

The level of price elasticities available in the literature depends on the methodological approach utilized. For the U.S., elasticities are markedly lower than one when stock is employed as the dependent variable (Riddel, 2004). By contrast, they are clearly above unity (and even close to 2 ) when a flow approach is used (Poterba, 1984; Topel and Rosen, 1988; Blackley, 1999). The scanty evidence available for other developed countries shows values below those of the U.S. For example, the 1.35 calculated for Switzerland by Steiner (2010) or the range of 0.72 to 1.02 obtained by Kenny (2003) for Ireland.

Caldera Sánchez and Johansson (2013) confirm that the response of supply to changes in price is relatively greater in the U.S. and in some Nordic countries than in the U.K. or continental Europe. Concretely, the estimations of the study cited show a price elasticity of supply of 0.5 for Spain, as against, for example, 2.0 in the U.S., 1.4 in Sweden or 1.2 for Denmark. Price elasticities lower than unity have also been obtained for the Spanish case by Sawaya Neto (2005) and Taltavull de la Paz (2006). The low price elasticities of supply are a symptom of their scanty capacity to respond to changes in residential investment demand, which generates bottlenecks in the property market (OECD, 2011). This different 
Exhibit 6 | Mortgage Rates

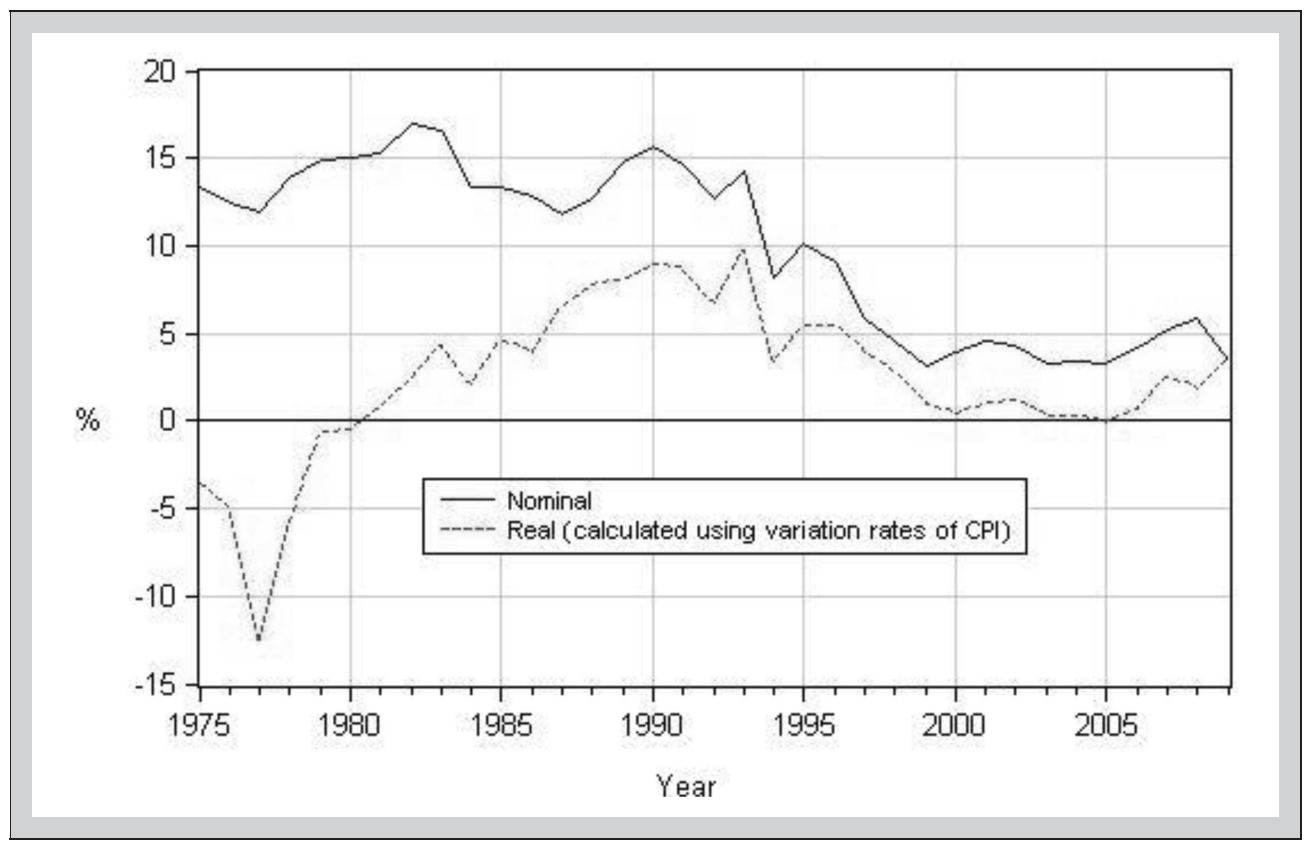

capacity of supply response can help us to understand, at least in part, why housing prices have increased, for example, by approximately double in Spain than in the U.S.

The evidence available for long-term income elasticities of supply is much scantier. The values obtained for the U.S. are positive and lower than unity, oscillating between 0 and 0.7 (DiPasquale and Wheaton, 1994; Malpezzi and Mclennan, 2001; Riddel, 2004). For the U.K., Malpezzi and Mclennan (2001) obtained slightly higher elasticities (between 0.72 and 1.43) for the 1947 to 1995 period. Similarly, supply is very sensitive to increases in interest rates (Topel and Rosen, 1988; Blackley, 1999; Mayer and Sommerville, 2000; Kenny, 2003; Steiner, 2010). Lastly, the relationship observed between inflation and housing supply is also negative. Following Topel and Rosen (1988) and Blackley (1999), an increase of $1 \%$ in the inflation rate would reduce supply by $8 \%$, while for Poterba (1984) this variation would provoke a reduction of between $0.93 \%$ and $3.13 \%$.

\section{Demand Elasticities}

The evidence shows that demand is, in the long term, more elastic to income changes than price changes. As Exhibit 7 shows, price elasticities oscillate between -0.09 and -0.46 , while the range of income elasticity is between 0.25 
Exhibit 7 | Long-run Housing Supply and Demand Elasticities in Developed Countries

\begin{tabular}{|c|c|c|c|c|c|c|c|c|}
\hline \multirow[b]{3}{*}{ Paper } & \multirow[b]{3}{*}{ Country/Data } & \multicolumn{5}{|l|}{ Elasticities } & \multirow{3}{*}{$\begin{array}{l}\text { Stock Adjustment } \\
\text { Process }\end{array}$} & \multirow{3}{*}{$\begin{array}{l}\text { Dependent } \\
\text { Variable }\end{array}$} \\
\hline & & \multicolumn{2}{|l|}{ Price } & \multicolumn{2}{|l|}{ Income } & \multirow[b]{2}{*}{ Other Elasticities } & & \\
\hline & & Supply & Demand & \multirow[t]{2}{*}{ Supply } & \multirow[t]{2}{*}{ Demand } & & & \\
\hline Panel A: U.S. & & & & & & & & \\
\hline $\begin{array}{l}\text { Poterba } \\
\text { (1984) }\end{array}$ & $\begin{array}{l}\text { U.S. } \\
\text { 1964-1982 (Q) }\end{array}$ & 0.52 to 2.96 & - & - & - & $\begin{array}{l}\text { Non-residential construction } \\
\text { deflator: }-0.93 \text { to }-3.13 \\
\text { Real construction wage: } \\
-0.20\end{array}$ & $\begin{array}{l}11 \text { years to reach } \\
\text { equilibrium }\end{array}$ & \\
\hline $\begin{array}{l}\text { Topel \& Rosen } \\
\text { (1988) }\end{array}$ & $\begin{array}{l}\text { U.S. } \\
\text { 1963-1983 (Q) }\end{array}$ & 1.4 to 2.2 & - & - & - & $\begin{array}{l}\text { Annual rate of interest: } \\
-8.0 \text { expected rate of } \\
\text { inflation: }-8.0\end{array}$ & - & $\begin{array}{l}\text { New single family } \\
\text { units started }\end{array}$ \\
\hline $\begin{array}{l}\text { DiPasquale \& } \\
\text { Wheaton } \\
\text { (1994) }\end{array}$ & $\begin{array}{l}\text { U.S. } \\
\text { 1963-1990 (A) }\end{array}$ & $\begin{array}{l}1.0 \text { to } 1.2 \\
1.2 \text { to } 1.4\end{array}$ & -0.09 to -0.19 & 0.3 to 0.7 & & $\begin{array}{l}\text { Demand-user cost: } \\
-0.004\end{array}$ & $\begin{array}{l}\text { Very slow stock } \\
\text { adjustment process } \\
\text { ( } 2 \% \text { annual) }\end{array}$ & $\begin{array}{l}\text { Housing starts / } \\
\text { stock }\end{array}$ \\
\hline $\begin{array}{l}\text { Blackley } \\
\text { (1999) }\end{array}$ & $\begin{array}{l}\text { U.S. } \\
\text { 1950-1994 (A) }\end{array}$ & 2.0 to 3.3 & - & - & - & $\begin{array}{l}\text { Materials: } \\
-0.5 \text { to }-1.37 \\
\text { Real interest: } \\
-5.9 \text { to }-7.3 \\
\text { Inflation: }-8.0\end{array}$ & $\begin{array}{l}\text { Fairly rapid movement } \\
\text { to equilibrium }\end{array}$ & $\begin{array}{l}\text { Residential } \\
\text { construction }\end{array}$ \\
\hline $\begin{array}{l}\text { Malpezzi \& } \\
\text { Maclennan } \\
\text { (2001) }\end{array}$ & $\begin{array}{l}\text { U.S. } \\
\text { 1889-1994 (A) }\end{array}$ & $\begin{array}{l}\text { (Pre-1947) } \\
4 \text { to } 10 \\
\text { (Post-1947) } \\
6 \text { to } 13\end{array}$ & - & $\begin{array}{l}\text { (Pre-1947) } \\
0 \\
\text { (Post-1947) } \\
0 \text { to } 0.68\end{array}$ & - & - & - & $\begin{array}{l}\text { New residential } \\
\text { construction }\end{array}$ \\
\hline Riddel (2004) & $\begin{array}{l}\text { U.S. } \\
\text { 1964-1999 (A) }\end{array}$ & 0.26 & -0.27 & 0.63 & 0.25 & $\begin{array}{l}\text { Demand rental-price: } 0.3 \\
\text { Demand-user cost: } \\
\text { non-significant }\end{array}$ & $\begin{array}{l}\text { The increase in prices } \\
\text { reactivates supply, } \\
\text { with a lag of } 2 \text { years }\end{array}$ & $\begin{array}{l}\text { Stock of } \\
\text { residential units }\end{array}$ \\
\hline
\end{tabular}


Exhibit 7 | (continued)

Long-run Housing Supply and Demand Elasticities in Developed Countries

\begin{tabular}{|c|c|c|c|c|c|c|c|c|}
\hline \multirow{2}{*}{ Paper } & \multirow{2}{*}{ Country / Data } & \multicolumn{5}{|l|}{ Elasticities } & \multirow{2}{*}{$\begin{array}{l}\text { Stock Adjustment } \\
\text { Process }\end{array}$} & \multirow{2}{*}{$\begin{array}{l}\text { Dependent } \\
\text { Variable }\end{array}$} \\
\hline & & \multicolumn{2}{|l|}{ Price } & \multicolumn{2}{|l|}{ Income } & Other Elasticities & & \\
\hline $\begin{array}{l}\text { Ball et al. } \\
(2010)\end{array}$ & $\begin{array}{l}\text { U.S. } \\
1970-2007 \text { (Q) }\end{array}$ & 0.48 & - & - & - & $\begin{array}{l}\text { Construction costs: }-0.61 \\
\text { Short term interest rate: } \\
-0.03\end{array}$ & - & New construction \\
\hline \multicolumn{9}{|c|}{ Panel B: Other OECD countries } \\
\hline $\begin{array}{l}\text { Ball et al. } \\
(2010)\end{array}$ & $\begin{array}{l}\text { Australia } \\
\text { 1983-2008 (Q) }\end{array}$ & 0.55 & - & - & & $\begin{array}{l}\text { Construction costs: }-0.92 \\
\text { Short term interest rate: } \\
-0.01\end{array}$ & - & New construction \\
\hline $\begin{array}{l}\text { Lee et al. } \\
\text { (2001) }\end{array}$ & $\begin{array}{l}\text { Austria } \\
\text { 1969-1996 (A) }\end{array}$ & - & -0.37 to -0.46 & - & $\begin{array}{l}-0.74 \text { to } \\
1.23\end{array}$ & $\begin{array}{l}\text { Population under } 20: \\
0.63 \text { to } 1.36\end{array}$ & - & $\begin{array}{l}\text { Residential } \\
\text { capital stock }\end{array}$ \\
\hline $\begin{array}{l}\text { Sawaya } \\
\text { (2005) }\end{array}$ & $\begin{array}{l}\text { Spain } \\
\text { January 1989- } \\
\text { April } 2000(Q)\end{array}$ & 0.68 to 1.16 & - & - & - & - & - & Housing starts \\
\hline $\begin{array}{l}\text { Fernandez- } \\
\text { Krantz \& Hon } \\
(2006)\end{array}$ & $\begin{array}{l}\text { Spain } \\
1996-2002 \\
\text { (A)(P) }\end{array}$ & - & - & - & 0.75 to 0.95 & - & - & $\begin{array}{l}\text { Expenditure on } \\
\text { housing }\end{array}$ \\
\hline
\end{tabular}


Exhibit 7 | (continued)

Long-run Housing Supply and Demand Elasticities in Developed Countries

\begin{tabular}{|c|c|c|c|c|c|c|c|c|}
\hline \multirow[b]{3}{*}{ Paper } & \multirow[b]{3}{*}{ Country/Data } & \multicolumn{5}{|l|}{ Elasticities } & \multirow{3}{*}{$\begin{array}{l}\text { Stock Adjustment } \\
\text { Process }\end{array}$} & \multirow{3}{*}{$\begin{array}{l}\text { Dependent } \\
\text { Variable }\end{array}$} \\
\hline & & \multicolumn{2}{|l|}{ Price } & \multicolumn{2}{|l|}{ Income } & \multirow[b]{2}{*}{ Other Elasticities } & & \\
\hline & & Supply & Demand & Supply & Demand & & & \\
\hline $\begin{array}{l}\text { Taltavull de la } \\
\text { Paz (2006) }\end{array}$ & $\begin{array}{l}\text { Spain } \\
1987-2004 \\
(Q)(P)\end{array}$ & 0.46 & - & - & - & $\begin{array}{l}\text { Interest rate: } \\
\text { not-significant. } \\
\text { Construction wages: }-2.26\end{array}$ & - & Housing starts \\
\hline $\begin{array}{l}\text { Knudsen } \\
\text { (1994) }\end{array}$ & $\begin{array}{l}\text { Denmark } \\
\text { 1971-1987 (Q) }\end{array}$ & - & -0.4 & - & 1.0 & - & - & $\begin{array}{l}\text { Residential } \\
\text { investment }\end{array}$ \\
\hline Kenny (2003) & $\begin{array}{l}\text { Ireland } \\
1975-1998(Q)\end{array}$ & 0.72 to 1.02 & - & - & - & $\begin{array}{l}\text { Interest rates: }-1.16 \text { to } \\
-2.19 \\
\text { Construction costs: }-0.16 \\
\text { to }-0.48\end{array}$ & - & $\begin{array}{l}\text { Private new } \\
\text { houses completed }\end{array}$ \\
\hline $\begin{array}{l}\text { Steiner } \\
(2010)\end{array}$ & $\begin{array}{l}\text { Swiss } \\
1975-2007 \text { (A) }\end{array}$ & 1.35 & -0.16 & - & 0.91 & $\begin{array}{l}\text { Supply-construction costs: } \\
-2.12 \\
\text { Supply-real interest rate: } \\
-3.8\end{array}$ & - & Housing stock \\
\hline $\begin{array}{l}\text { Mayer \& } \\
\text { Somerville } \\
(2000)\end{array}$ & $\begin{array}{l}\text { U.K. } \\
\text { 1975-1994 (Q) }\end{array}$ & $\begin{array}{l}3.7 \\
0.08\end{array}$ & - & - & - & $\begin{array}{l}\text { Interest rates: } \\
-3.49 \text { to }-4.85\end{array}$ & - & $\begin{array}{l}\text { Housing start / } \\
\text { stock }\end{array}$ \\
\hline $\begin{array}{l}\text { Malpezzi \& } \\
\text { Maclennan } \\
\text { (2001) }\end{array}$ & $\begin{array}{l}\text { U.K } \\
1850-1995 \text { (A) }\end{array}$ & $\begin{array}{l}\text { (Pre-1947) } \\
1 \text { to } 4 \\
\text { (Post-1947) } \\
0 \text { to } 1\end{array}$ & - & $\begin{array}{l}\text { (Pre-1947) } \\
0 \text { to } 0.558 \\
\text { (Post-1947) } \\
0.72 \text { to } 1.43\end{array}$ & - & - & - & $\begin{array}{l}\text { New residential } \\
\text { construction }\end{array}$ \\
\hline $\begin{array}{l}\text { Notes: } \\
\text { (A) Annual dat } \\
\text { (Q) Quarterly } \\
\text { (P) Panel data }\end{array}$ & & & & & & & & \\
\hline
\end{tabular}


and around the unity (DiPasquale and Wheaton, 1994; Knudsen, 1994; Lee, Schmidt-Dengler, Felderer, and Helmenstein, 2001; Riddel, 2004; FernándezKranz and Hon, 2006; Steiner, 2010). The greater response to income changes is an expected result, given that housing is a durable good, which requires a considerable financial effort over many years. In Spain, during the years prior to the latest boom analyzed, the average nominal price of housing was equivalent to the available income generated by an average household during a four-year period. The peak of the price income ratio (PIR) was reached at the end of the boom, with a value of close to eight years. Despite the sharp fall in housing prices commented upon in the previous section, the PIR was 6.2 years at the beginning of 2013, still far from the four years prior to the boom. Some authors, such as García Montalvo (2012), state that unemployment rates of over 25\%, together with a sharp fall in available household income (14.7\% between 2008 and 2012) will continue to push the PIR downwards in coming years).

Other factors influence the behavior of demand; amongst these should be underlying population growth, the user cost or the price of housing rental. For Austria, Lee, Schmidt-Dengler, Felderer, and Helmenstein, (2001) estimate that the stock elasticity of housing with regard to the population over age 20 ranges between 0.63 and 1.36. The evidence available for Spain shows that the increase in the population has exercised strong pressure on housing prices (Ayuso, Martinez, Maza, and Restoy, 2003; OECD, 2004). Moreover DiPasquale and Wheaton (1994) show that demand elasticity to the user cost is -0.004 , while Riddel (2004) finds that it does not prove to be significant. Lastly, Riddel (2004) finds that housing demand is sensitive to changes in rental prices, with an elasticity of 0.3, which indicates that the two goods demonstrate a certain degree of substitutability. By contrast, in the short run the results of Barrios and Rodríguez (2005) show for the Spanish case that this relationship of substitutability is close to zero. This result was expected, given the traditional Spanish preference for home ownership instead of rental. To finalize the international comparison, Exhibit 7 offers evidence of the rhythm at which supply and demand adjust in situations of disequilibria. The results obtained by Poterba (1984) and DiPasquale and Wheaton (1994) reveal that the rhythm of adjustment is very slow; it can be reached in a period of 11 years.

\section{Empirical Model}

The model employed is based on the methodology proposed by DiPasquale and Wheaton (1994). It is based on the fact that housing demand (in terms of stock) depends on a set of exogenous variables $\left(X_{1}\right)$, such as demographic variables, permanent income, etc. In addition, it depends on housing prices $(P)$ and user cost $(U)$. Thus:

$$
D\left(X_{1}, P, U\right)=S_{D}
$$


Similarly, housing supply (in terms of stock) is determined using the differential equation:

$$
\Delta S_{S}=C\left(X_{2}, P\right)-\delta S_{s}
$$

where housing stock depreciates at a rate $\delta$ and expands with new construction $(C)$, which depends on the price of housing $(P)$ and on a set of exogenous variables $\left(X_{2}\right)$, such as construction costs and financing costs.

For equilibrium to exist in the housing market, supply and demand must be equal, $S^{*}=S_{S}=S_{D}$, such that $P^{*}=P$. However, the presence of transaction costs and the existence of phenomena typical of this sector, such as the long period elapsing between the instant in which housing start decisions are taken and the moment at which they are finalized, mean that the housing market may be far from equilibrium over long periods (DiPasquale and Wheaton, 1994; Meen, 2002, 2008). Thus, the prices and housing stock observed ( $P_{O}$ and $S_{O}$, respectively) are not generally in equilibrium. Furthermore, such variables are not generally stationary; however, it is expected that the variables $\omega_{1}=\left(S^{*}-S_{O}\right)$ and $\omega_{2}=$ $\left(P^{*}-P_{O}\right)$ are stationary. Thus, the dynamic of the relations between these variables and their adjustment can be tackled from the perspective of error correction models. If the existence of linearity is assumed (e.g., DiPasquale and Wheaton, 1994; Meen, 2002; Riddel, 2004; Andrews, Caldera Sánchez, and Johansson, 2013), the following is obtained: ${ }^{9}$

$$
\begin{aligned}
& \Delta S_{O}=\alpha_{1}+\beta_{1}\left(S^{*}\left(P^{*}\right)-S_{O}\right)+\lambda_{1} X_{3}+\varepsilon_{1} . \\
& \Delta P_{O}=\alpha_{2}+\beta_{2}\left(P^{*}\left(S^{*}\right)-P_{O}\right)+\lambda_{2} X_{3}+\varepsilon_{2} .
\end{aligned}
$$

On the basis of equations (3) and (4), the dynamic of adjustment in the property market can be analyzed. The parameters $\beta_{1}$ and $\beta_{2}$ determine the speed at which the property market adjusts in situations of disequilibria: $\beta_{1}$ for housing stock and $\beta_{2}$ for prices. To obtain the empirical model, we also assume a linear functional form for supply and demand:

$$
\begin{aligned}
S_{D} & =\delta_{0}+\delta_{1} P+\delta_{2} \text { Pop }+\delta_{3} \text { Income }+\delta_{4} \text { Wealth } \\
& +\delta_{5} \text { Interest rates }+\delta_{6} \text { Unemployment } \\
S_{S} & =\mu_{0}+\mu_{1} P+\mu_{2} \text { Construction costs }+\mu_{3} \text { Interest rates },
\end{aligned}
$$


with the expected signs:

$$
\begin{aligned}
& \delta_{1}, \delta_{5} y \delta_{6}<0 \quad \delta_{2}, \delta_{3} y \delta_{4}>0 \\
& \mu_{1}>0 \quad \mu_{2} y \mu_{3}<0
\end{aligned}
$$

Equation (5) shows that demand in real terms for housing stock depends on its real prices $(P)$, on population factors $(P o p)$, on the evolution of the permanent income of households (Income) and on their wealth (Wealth), on the user cost (approximated by interest rates) ${ }^{10}$ (Interest rates), and on the labor market situation, approximated, for example, through some measure of unemployment (Unemployment). Equation (6) shows that supply is determined by price levels, by the costs of the construction and rehabilitation of dwellings (Construction costs), and by the costs of financing of housing investment projects, approximated by interest rates (Interest rates). The selection of the variables determining supply and demand is in full accordance with the suggestions of economic theory and with the usual assumptions in the empirical literature on the analysis of the housing market (e.g., DiPasquale and Wheaton, 1994; Meen, 2002, 2008; Wigren and Wilhelmsson, 2007).

Considering the situation of equilibrium, in which $S^{*}=S_{S}=S_{D}$ and $P^{*}=P$ and resolving the system:

$$
\begin{aligned}
\Delta S_{O} & =\gamma_{10}+\gamma_{11} \text { Pop }+\gamma_{12} \text { Income }+\gamma_{13} \text { Wealth } \\
& +\gamma_{14} \text { Interest rates }+\gamma_{15} \text { Unemployment } \\
& +\gamma_{16} \text { Construction costs }-\beta_{1} S_{O}+\lambda_{1} X_{3}+\varepsilon_{1} . \\
\Delta P_{O} & =\gamma_{20}+\gamma_{21} \text { Pop }+\gamma_{22} \text { Income }+\gamma_{23} \text { Wealth } \\
& +\gamma_{24} \text { Interest rates }+\gamma_{25} \text { Unemployment } \\
& +\gamma_{26} \text { Construction costs }-\beta_{2} P_{O}+\lambda_{2} X_{3}+\varepsilon_{2} .
\end{aligned}
$$

Moreover, when modeling the adjustment towards equilibrium, it is considered in line with the usual practice in the literature (DiPasquale and Wheaton, 1994; Malpezzi and Mclennan, 2001; Riddel, 2004) that the process of adjustment is determined by the disequilibrium between $\left(S_{t}^{*}-S_{O(t-1)}\right)$ and $\left(P_{t}^{*}-P_{O(t-1)}\right)$, such that in equations (7) and (8), $S_{O}$ and $P_{O}$ are lagged.

As can be observed, equations (7) and (8) are reduced form equations. With the exception of the parameters $\beta_{1}$ and $\beta_{2}$, which determine the speed at which the property market adjusts to situations of disequilibria, the remaining parameters of 
equations (7) and (8) have no structural interpretation. The estimation of the elasticities of housing stock supply and demand is obtained on the basis of equation (3), employing in that estimation a consistent approximation of $P^{*}$.

\section{Data}

The variables are in full accordance with our empirical model. Exhibit A.1 in Appendix A presents the definition of the variables and their source. Although the variables employed in the estimation of the model have already been presented, there are various important aspects that need to be mentioned.

One problem we faced in the estimation was the scanty and fragmented information existing in Spain with regard to the evolution of prices in the property sector. In fact, to be able to have available a price series that covered the period analyzed (1975-2009) three distinct datasets from three distinct sources were combined: for 1975-1990, the source is Escosura (2003); for 1990-2007, the data from Uriel Jiménez et al. (2009) were used; and for 2007-2009, we employed data from the Instituto Nacional de Estadística. ${ }^{11}$ The endogenous variable considered was gross housing stock in real terms, although the model was also estimated on the basis of real net stock, obtaining results similar to those obtained with gross stock. ${ }^{12}$

As a proxy variable of household wealth, a household financial wealth variable is used. ${ }^{13}$ This variable only includes financial assets. It does not include property variables, thereby avoiding the appearance of endogeneity problems additional to those generated by prices and gross household stock. The econometric analysis considers the variable in real terms. The series is deflated by employing the Consumer Price Index (CPI) for Spain (see Exhibit A.1 of Appendix A). When the real household financial wealth variable is introduced into the analysis, it is necessary to restrict the sample to the 1989-2009 period, due to the lack of data.

The measurement of interest rates employed is mortgage interest rates, precisely because these interest rates are linked to the activity of the property market. The series is deflated by employing the CPI for Spain (see Exhibit A.1 of Appendix A).

The total population was employed as the demographic variable. ${ }^{14}$ To measure permanent income, GDP per capita was considered. ${ }^{15}$ The unemployment rate was used to measure the labor market situation. ${ }^{16}$ An index of construction materials costs, deflated by the CPI, was employed for the construction and financial costs of housing supply (see Exhibit A.1 of Appendix A).

\section{Results of the Estimation of the Reduced Form Equations}

The empirical literature provides models of determination of housing supply and demand not only in levels (DiPasquale and Wheaton, 1994; Blackley, 1999) but

\begin{tabular}{l|l|lll} 
JRER & $\mathrm{V} \circ \mathrm{I} .37$ & $\mathrm{~N} \circ .3-2015$ \\
\hline
\end{tabular}


also in logarithms (Meen, 2002; Riddel, 2004; Wigren and Wilhelmsson, 2007). We use a logarithmic formulation, ${ }^{17}$ which permits the interpretation of the structural parameters estimated in terms of elasticities. ${ }^{18}$ In this regard, Exhibit 8 shows the estimations obtained for equations (7) and (8). ${ }^{19,20}$ Two sample periods were employed, according to whether the study incorporated a measure of household wealth (columns 5, 6, 11, and 12 of Exhibit 8) or not (columns 1-4 and 7-10 of Exhibit 8). As can be seen (columns 3, 4, 9, and 10 of Exhibit 8), an attempt was made to incorporate dummy variables to capture possible changes in the averages of the endogenous variables linked to the housing booms and not explained by the remaining variables. However, these variables did not prove to be statistically significant and were not included in the analysis.

Given the non-stationary character of the variables ${ }^{21}$ the significance of the lag of housing stock and of prices in the respective equations constitutes evidence of the possible existence of a long-term equilibrium relationship between equilibrium stock and that observed and between equilibrium prices and those observed. ${ }^{22}$ The inclusion of a measure of real household financial wealth (columns 5, 6, 11, and 12 of Exhibit 8) was unsatisfactory for two reasons. Firstly, because this means considerably reducing the sample size, with the implications this has from the point of view of the properties of the estimators. Secondly, because the real financial wealth variable is not always significant. Additionally, when it is significant (column (5) of Exhibit 8), it does not appear to display a very different effect to that captured by GDP per capita, which becomes non-significant. ${ }^{23}$

Taking all these considerations into account, the decision was to take as reference models those estimated for the sample period 1975-2009; these appear in columns (1) and (7) of Exhibit 8. Thus, and with regard to the economic interpretation of the results, it must be emphasized that in the context of the equilibrium equations (7) and (8), the signs obtained for the effects of the different variables coincide with expectations. For example, increases in population, permanent income, and wealth produce rises in the long-term housing stock, while increases in real interest rates, construction costs, and the unemployment rate reduce gross housing stock (see column 1 of Exhibit 8). With regard to the models for variations in real housing prices, the results show that with the exception of the effect of the variable that measures permanent income, the explanatory variables have the expected sign, although in this case GDP per capita is not statistically significant (see column 7 in Exhibit 8). Nevertheless, the reduced form character of these models does not permit a structural interpretation of these relationships to be proposed.

Furthermore, it is of great interest to study the parameters representing the factors of adjustment towards equilibrium of both gross stock and prices. A very interesting conclusion is that the adjustment process is much slower for stock than for prices. In this regard, it is useful to measure the average lag that elapses since a change occurs in stock and equilibrium prices until its complete transmission to the stock and prices observed. The stock adjustment period is approximately 13 years, while for prices it is some 2 or 3 years. Behind this result is the rigidity inherent in the production/consumption of dwellings. It is impossible to construct 
Exhibit 8 | Reduced Form Equations

\begin{tabular}{|c|c|c|c|c|c|c|c|c|c|c|c|c|}
\hline & \multicolumn{6}{|c|}{ Real Gross Housing Stock } & \multicolumn{6}{|c|}{ Real Housing Prices } \\
\hline & (1) & $(2)$ & (3) & (4) & $(5 V)$ & (6) & (7) & (8) & (9) & (10) & (11) & (12) \\
\hline Constant & $\begin{array}{c}0.194^{*} \\
(0.254)\end{array}$ & $\begin{array}{c}0.208^{*} \\
(0.220)\end{array}$ & $\begin{array}{c}0.096^{*} \\
(0.288)\end{array}$ & $\begin{array}{c}0.123^{*} \\
(0.236)\end{array}$ & $\begin{array}{r}-0.366^{*} \\
(0.664)\end{array}$ & $\begin{array}{c}0.173^{*} \\
(0.711)\end{array}$ & $\begin{array}{r}-13.952 \\
(6.900)\end{array}$ & $\begin{array}{r}-28.674 \\
(8.638)\end{array}$ & $\begin{array}{r}-10.278 \\
(6.892)\end{array}$ & $\begin{array}{r}-21.493 \\
(9.507)\end{array}$ & $\begin{array}{r}-53.780 \\
(24.980)\end{array}$ & $\begin{array}{r}-54.264 \\
(24.980)\end{array}$ \\
\hline Stockb $_{t-1}$ & $\begin{array}{r}-0.069 \\
(0.031)\end{array}$ & $\begin{array}{r}-0.102 \\
(0.030)\end{array}$ & $\begin{array}{r}-0.063^{*} \\
(0.035)\end{array}$ & $\begin{array}{r}-0.108^{*} \\
(0.030)\end{array}$ & $\begin{array}{r}-0.110 \\
(0.061)\end{array}$ & $\begin{array}{r}-0.135 \\
(0.060)\end{array}$ & - & - & - & - & - & - \\
\hline Real housing prices ${ }_{t-1}$ & - & - & - & - & - & - & $\begin{array}{r}-0.297 \\
(0.066)\end{array}$ & $\begin{array}{r}-0.472 \\
(0.092)\end{array}$ & $\begin{array}{r}-0.174 \\
(0.074)\end{array}$ & $\begin{array}{r}-0.332 \\
(0.074)\end{array}$ & $\begin{array}{r}-0.577 \\
(0.240)\end{array}$ & $\begin{array}{r}-0.547 \\
(0.139)\end{array}$ \\
\hline Population & $\begin{array}{c}0.108 \\
(0.053)\end{array}$ & $\begin{array}{c}0.163 \\
(0.051)\end{array}$ & $\begin{array}{c}0.108^{*} \\
(0.058)\end{array}$ & $\begin{array}{c}0.182 \\
(0.052)\end{array}$ & $\begin{array}{c}0.235 \\
(0.071)\end{array}$ & $\begin{array}{c}0.217 \\
(0.080)\end{array}$ & $\begin{array}{c}1.567 \\
(0.808)\end{array}$ & $\begin{array}{c}3.134 \\
(0.968)\end{array}$ & $\begin{array}{c}1.189 \\
(0.854)\end{array}$ & $\begin{array}{c}2.384 \\
(1.049)\end{array}$ & $\begin{array}{c}6.172 \\
(2.764)\end{array}$ & $\begin{array}{c}6.463 \\
(1.578)\end{array}$ \\
\hline Real interest rates & $\begin{array}{r}-0.040 \\
(0.015)\end{array}$ & $\begin{array}{r}-0.047 \\
(0.016)\end{array}$ & $\begin{array}{r}-0.038 \\
(0.016)\end{array}$ & $\begin{array}{r}-0.047 \\
(0.017)\end{array}$ & $\begin{array}{r}-0.032 * \\
(0.027)\end{array}$ & $\begin{array}{r}-0.010^{*} \\
(0.026)\end{array}$ & $\begin{array}{c}0.077^{*} \\
(0.225)\end{array}$ & $\begin{array}{c}-0.187^{*} \\
(0.229)\end{array}$ & $\begin{array}{c}0.286^{*} \\
(0.311)\end{array}$ & $\begin{array}{c}0.051^{*} \\
(0.288)\end{array}$ & $\begin{array}{r}-0.450^{*} \\
(0.527)\end{array}$ & $\begin{array}{r}-1.397 \\
(0.368)\end{array}$ \\
\hline Real construction costs ${ }_{t-1}$ & $\begin{array}{r}-0.023^{*} \\
(0.013)\end{array}$ & $\begin{array}{r}-0.026 \\
(0.012)\end{array}$ & $\begin{array}{r}-0.024^{*} \\
(0.014)\end{array}$ & $\begin{array}{r}-0.026^{*} \\
(0.012)\end{array}$ & $\begin{array}{r}-0.039 \\
(0.017)\end{array}$ & $\begin{array}{r}-0.050 \\
(0.022)\end{array}$ & $\begin{array}{r}-0.423^{*} \\
(0.264)\end{array}$ & $\begin{array}{r}-0.523 \\
(0.245)\end{array}$ & $\begin{array}{c}-0.397^{*} \\
10.375\end{array}$ & $\begin{array}{r}-0.483^{*} \\
(0.245)\end{array}$ & $\begin{array}{r}-1.335 \\
(0.445)\end{array}$ & $\begin{array}{r}-1.447 \\
(0.265)\end{array}$ \\
\hline Unemployment rate & $\begin{array}{r}-0.106 \\
(0.013)\end{array}$ & $\begin{array}{r}-0.095 \\
(0.013)\end{array}$ & $\begin{array}{r}-0.105 \\
(0.016)\end{array}$ & $\begin{array}{r}-0.091 \\
(0.014)\end{array}$ & $\begin{array}{r}-0.100 \\
(0.033)\end{array}$ & $\begin{array}{r}-0.088 \\
(0.034)\end{array}$ & $\begin{array}{r}-1.651 \\
(0.337)\end{array}$ & $\begin{array}{r}-1.992 \\
(0.337)\end{array}$ & $\begin{array}{r}-1.174 \\
(0.418)\end{array}$ & $\begin{array}{r}-1.578 \\
(0.421)\end{array}$ & $\begin{array}{r}-2.899 \\
(0.702)\end{array}$ & $\begin{array}{r}-3.084 \\
(0.421)\end{array}$ \\
\hline
\end{tabular}


Exhibit 8 | (continued)

Reduced Form Equations

\begin{tabular}{|c|c|c|c|c|c|c|c|c|c|c|c|c|}
\hline & \multicolumn{6}{|c|}{ Real Gross Housing Stock } & \multicolumn{6}{|c|}{ Real Housing Prices } \\
\hline & (1) & (2) & (3) & (4) & (5V) & (6) & (7) & (8) & (9) & (10) & (11) & (12) \\
\hline GDP per capita & $\begin{array}{r}0.015^{*} \\
(0.013)\end{array}$ & $\begin{array}{c}0.025 \\
(0.012)\end{array}$ & $\begin{array}{c}0.012^{*} \\
(0.014)\end{array}$ & $\begin{array}{c}0.025^{*} \\
(0.013)\end{array}$ & $\begin{array}{r}0.009^{*} \\
(0.037)\end{array}$ & $\begin{array}{r}0.032^{*} \\
(0.037)\end{array}$ & $\begin{array}{r}-0.253^{*} \\
(0.187)\end{array}$ & $\begin{array}{c}-0.448 \\
(0.188)\end{array}$ & $\begin{array}{r}-0.225^{*} \\
(0.233)\end{array}$ & $\begin{array}{r}-0.373^{*} \\
(0.188)\end{array}$ & $\begin{array}{c}-1.215 \\
(0.498)\end{array}$ & $\begin{array}{c}-1.375 \\
(0.498)\end{array}$ \\
\hline Real financial wealth & - & - & - & - & $\begin{array}{c}0.009 \\
(0.004)\end{array}$ & $\begin{array}{r}0.005^{*} \\
(0.006)\end{array}$ & - & - & - & - & $\begin{array}{c}0.037^{*} \\
(0.086)\end{array}$ & $\begin{array}{r}-0.022^{*} \\
(0.041)\end{array}$ \\
\hline D85-91 & - & - & $\begin{array}{c}0.0005^{*} \\
(0.001)\end{array}$ & $\begin{array}{l}0.00011^{*} \\
(0.001)\end{array}$ & - & - & - & - & $\begin{array}{c}0.028^{*} \\
(0.015)\end{array}$ & $\begin{array}{c}0.018^{*} \\
(0.019)\end{array}$ & - & - \\
\hline D97-07 & - & - & $\begin{array}{c}0.0007^{*} \\
(0.001)\end{array}$ & $\begin{array}{c}0.001 * \\
(0.001)\end{array}$ & - & - & - & - & $\begin{array}{c}0.058^{*} \\
(0.032)\end{array}$ & $\begin{array}{c}0.039^{*} \\
(0.025)\end{array}$ & - & - \\
\hline Parameter $\rho_{1}$ of an $\operatorname{AR}(1)$ & - & $\begin{array}{r}0.168^{*} \\
(0.205)\end{array}$ & - & $\begin{array}{c}0.109^{*} \\
(0.213)\end{array}$ & - & $\begin{array}{c}0.234^{*} \\
(0.287)\end{array}$ & - & $\begin{array}{c}0.052^{*} \\
(0.180)\end{array}$ & & $\begin{array}{c}-0.001^{*} \\
(0.208)\end{array}$ & - & $\begin{array}{r}-0.910 \\
(0.199)\end{array}$ \\
\hline \multicolumn{13}{|l|}{ Liung-Box ( $p$-value) } \\
\hline$K=1$ & 0.262 & - & 0.345 & - & 0.932 & - & 0.431 & - & 0.995 & - & 0.046 & - \\
\hline$K=2$ & 0.383 & 0.283 & 0.344 & 0.151 & 0.183 & 0.019 & 0.535 & 0.618 & 0.446 & 0.460 & 0.097 & 0.009 \\
\hline$K=3$ & 0.371 & 0.549 & 0.309 & 0.343 & 0.321 & 0.024 & 0.412 & 0.515 & 0.323 & 0.434 & 0.164 & 0.013 \\
\hline
\end{tabular}


a dwelling from one day to the next, nor can it be made to disappear overnight. Furthermore, as housing is an investment and durable consumption good, it is fitting to expect that agents adjust prices more rapidly than housing stock, anticipating future rises and falls in long-term equilibrium prices to increase or decrease capital gains or losses.

\section{Structural Approximation: Estimation of Elasticities}

As stated, the parameters of equations (7) and (8) have no structural interpretation, except for the parameter that measures adjustment speed. Consequently, to identify and estimate consistently the supply and demand elasticities of the stock of dwellings, the following strategy has been followed: with the estimations obtained for equation (8) and assuming that $\alpha_{2}=0$, a consistent approximation of $P^{*}$ is obtained on the basis of:

$$
\begin{aligned}
P^{*} & =\frac{1}{\beta_{2}}\left(\gamma_{20}+\gamma_{21} \text { Pop }+\gamma_{22} \text { Income }+\gamma_{23}\right. \text { Wealth } \\
& +\gamma_{24} \text { Interest rates }+\gamma_{25} \text { Unemployment } \\
& \left.+\gamma_{26} \text { Construction costs }\right) .
\end{aligned}
$$

The structural parameters of the demand and supply functions are estimated on the basis of equation (3), employing (9) and equations (5) and (6) respectively. In this way, for the demand equation, the following is obtained:

$$
\begin{aligned}
\Delta S_{O} & =\gamma_{10}+\beta_{1} \delta_{1} P^{*}+\beta_{1} \delta_{2} \text { Pop }+\beta_{1} \delta_{3} \text { Income } \\
& +\beta_{1} \delta_{4} \text { Wealth }+\beta_{1} \delta_{5} \text { Interest rates } \\
& +\beta_{1} \delta_{6} \text { Unemployment }-\beta_{1} S_{O}+\lambda_{1} X_{3}+\varepsilon_{1}
\end{aligned}
$$

and for the supply equation it holds that:

$$
\begin{aligned}
\Delta S_{O} & =\gamma_{10}+\beta_{1} \mu_{1} P^{*}+\beta_{1} \mu_{2} \text { Construction costs } \\
& +\beta_{1} \mu_{3} \text { Interest rates }-\beta_{1} S_{O}+\lambda_{1} X_{3}+\varepsilon_{1} .
\end{aligned}
$$

Estimating (10) and (11), and once estimations of $\beta_{1}$ are available, consistent estimations of the structural parameters of demand and supply can be obtained. 
Exhibit 9 displays the estimations of models (10) and (11), both without imposing the estimations of adjustment speed $\left(\beta_{1}\right)$ obtained previously (columns 1 and 3) and imposing such estimations (columns 2 and 4 ). The estimations of the respective long-term elasticities are presented next to each of the columns. The housing stock demand elasticities have the expected signs and are statistically significant, while those of supply, although they always have the expected sign, are only significant when the adjustment speed $\beta_{1}$, obtained from the reduced form, is imposed.

The conceptual framework we propose appears to function better, from the econometric point of view, for demand than for supply. For demand, the estimated values of the parameters are very similar, independently of whether the value of the adjustment speed is imposed, while this does not occur for supply. Furthermore, the autocorrelation tests show no indication of poor specification in the case of demand, while for supply doubts exists, especially when the value of the adjustment speed is imposed.

The results show that demand is in the long term much less sensitive than supply to prices. As can be seen in Exhibit 9, the price elasticities for demand are -0.156 and -0.165 , according to whether the adjustment speed is imposed. This is close to the -0.16 obtained by Steiner (2010) for Switzerland, but clearly below the estimations for other European countries such as Austria or Denmark (Knudsen, 1994; Lee, Schmidt-Dengler, Felderer, and Helmenstei, 2001), which are approximately -0.40 . Possibly, this lower sensibility of housing demand to prices in Spain is related to the marked preference of Spaniards for home ownership, in comparison to its surrounding countries. According to Naredo, Carpintero, and Marcos (2009), in 2000 Spanish households maintained $69 \%$ of their wealth in property assets and only $9 \%$ in shares. The data show that $83.2 \%$ of Spanish households possessed a dwelling, a figure slightly above that of Ireland $(81.2 \%)$ and far greater than that of other countries with higher income per capita, such as the U.K. (70.7\%), the U.S. (68.7\%), Germany (41.0\%) or Switzerland $(38.4 \%)$ (Andrews and Caldera Sánchez, 2011).

Moreover, the estimations of the price elasticity of supply are considerably different according to whether the adjustment speed is imposed: 1.31 and 0.43 respectively. Such values are in line with the range of 0.68 to 1.16 estimated by Sawaya Neto (2005). These results are lower than those found in the U.S. and in some Nordic countries. Consequently, they show a poorer capacity of adaptation to changes in market conditions. One of the restrictions traditionally faced by housing supply in Spain is the marked rigidity of the supply of land (Banco de España, 2002; OECD, 2005, 2007; IMF, 2009). This shortage is due essentially to questions of a regulatory nature more than to population density, which is relatively low (93 inhabitants per square kilometer). Spanish legislation is very complex with regard to what land may be built on, how it may be built on, and even when it may be built on. Consequently, the production of land that may be built on is very slow, exercising great pressure upon land prices (Comisión Nacional de la Competencia, 2014). 
Exhibit 9 | Structural Equations

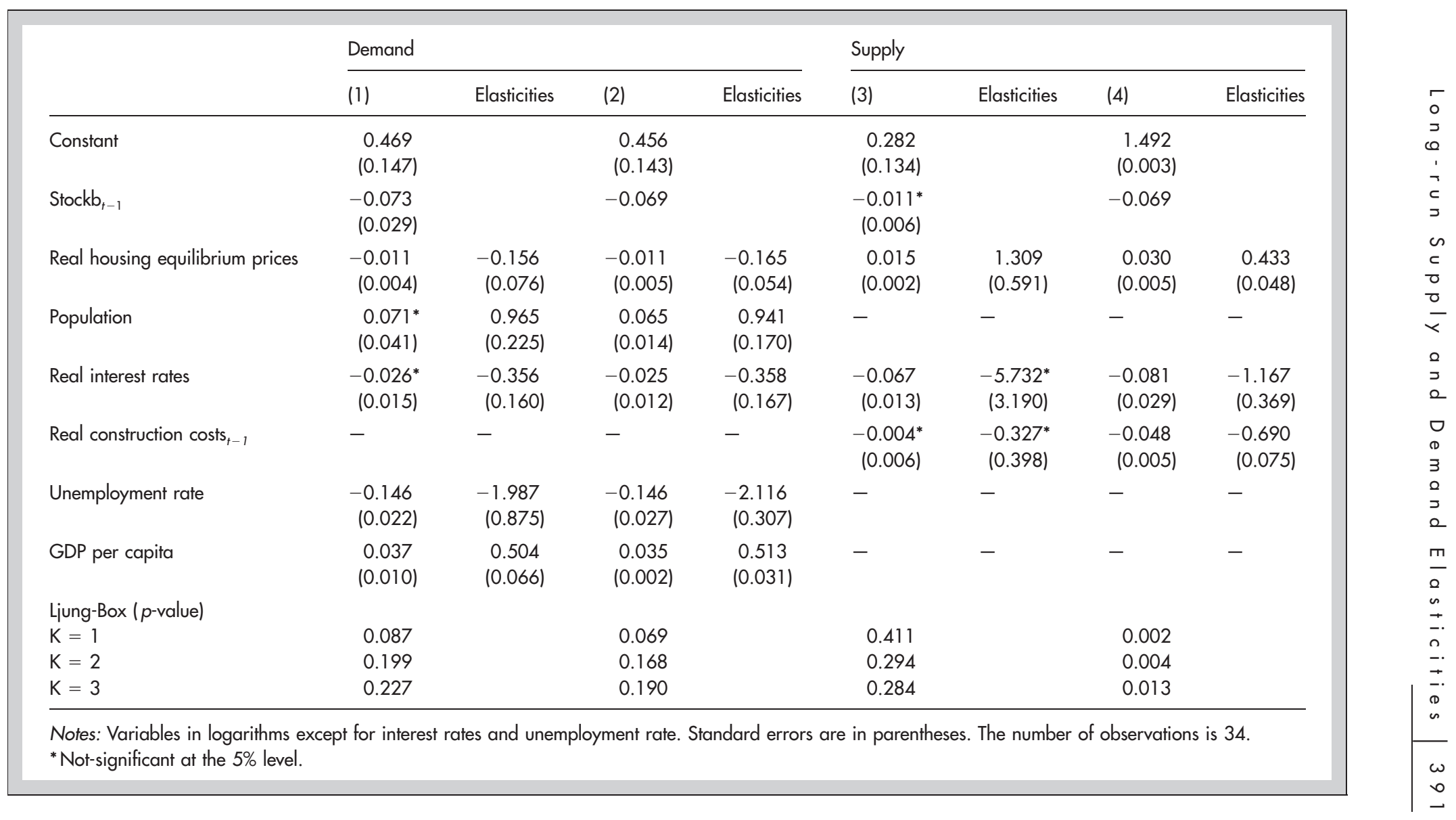


The estimations of the long-run income elasticity of demand were 0.50 and 0.51 . Such values are in line with the evidence available for Spain (Fernández-Krantz and Hon, 2006). One aspect worthy of emphasis is that, as seen in Section 2, both price elasticities and income demand elasticities are lower than unity. However, the results show that demand is more sensitive to changes in income than to changes in prices. A possible explanation of the low income elasticities we find is that the unemployment rate captures part of that effect, due to its strong relation to the economic cycle. The semielasticities of demand to the unemployment rate were -1.99 and -2.11 . Consequently, an increase of one percentage point in the unemployment rate would reduce demand by approximately $2 \%$. The evolution of the unemployment rate acts as a potential lever that increases or reduces housing demand. As seen in Section 2, this is an important question in a country such as Spain, one affected by high rates of unemployment.

As in the case of prices, demand is much less sensitive than supply to real interest rates. Specifically, the semielasticities of demand are -0.356 and -0.358 , while in the case of supply the values are -5.732 and -1.167 . The existence of semielasticities of supply with regard to changes in interest rates clearly exceeding unity has also been observed in Spain (Sawaya, 2005), as well as in the U.S., Ireland, Switzerland, and the U.K. (Topel and Rosen; 1988; Mayer and Sommerville, 2000; Kenny, 2003; Steiner, 2010). Similarly, supply is sensitive to an increase in construction costs when adjustment speed is imposed on the estimations. Specifically, the elasticity estimated is -0.69 , in line with that obtained for the U.S. or Ireland (Blackley, 1999; Kenny, 2003).

Lastly, population size exerts considerable pressure on demand, the elasticities obtained being 0.97 and 0.94 . These values, exceeding in absolute value price and income elasticities, show that population increase has been a key factor in the latest of the property booms analyzed. The elasticities obtained are in line with the range of 0.63 to 1.36 obtained for Austria by Lee, Schmidt-Dengler, Felderer, and Helmenstei (2001).

\section{Conclusion}

In this study, we estimate housing supply and demand elasticities for Spain for the 1975-2009 period. The results show that demand is in the long run largely insensitive to variations in prices and real interest rates. Conversely, demand is highly sensitive to the labor market situation and, to a lesser extent, to demographic changes. The results also reflect that demand is more sensitive to permanent income than to prices (in absolute values, 0.51 vs. 0.16). The evidence therefore shows that the economic cycle effect, measured in terms of changes in income and in the unemployment rate, has a greater weight than prices in the behavior of demand. Supply shows great sensitivity to variations in prices and interest rates. These marked differences in the behavior of supply and demand with regard to prices means that the Spanish property market is more prone to property bubbles. Additionally, the strong preference of Spaniards for home 
ownership, whether to be used as a residence or as an investment good, increases the probability that such bubbles are produced even when only slight improvements occur in average household income. This structural feature of the Spanish property market obliges public managers to be especially vigilant concerning those factors that may stimulate the latent exposure of the economy to real estate bubbles.

The latest property cycle experienced in Spain demonstrates that one of those key factors is the degree of laxity with which financial institutions grant mortgages, to both households and property developers. On this point, Akin et al. (2014) suggest for the Spanish case that mortgage spreads for the unemployed are identical to those for employed borrowers during the last boom. Similarly, GarciaMontalvo and Raya (2012) provide evidence that in this period the average ratio of the loan-to-market price was around 110\%, although the average loan-toappraisal ratio was $82 \%$, very close to the maximum level $(80 \%)$ recommended by the Bank of Spain.

With regard to the situations of disequilibria produced by the collapse of the bubble, the evidence shows that price adjustment is produced at a much faster pace than housing stock adjustment, estimated to be a maximum of 13 years. Seven years have passed since the end of the latest bubble, with an accumulated price reduction of nearly $30 \%$. Although high, the decrease has been much slower than that observed in Ireland or the U.S., where prices fell by $30 \%$ during the first three years after the bubble collapsed. In fact, the adjustment in the Spanish housing market has been more intensive in quantities than in prices. During the first three years of the crisis, the sale of dwellings in the U.S. dropped by $25 \%$, while in Spain the fall was 50\% (García-Montalvo, 2013). The decrease in prices in Spain is currently in the range of values observed in the property markets of Finland in the late 1970s $(-30 \%)$, of Italy in the early 1980s $(-30 \%)$, and of Japan and Sweden in the early 1990s (-27\%). However, as our results show, the duration of the adjustment continued in 2014 and is on the way to becoming one of the longest since the 1970s. ${ }^{24}$ On this point, the OECD estimations for 2013 establish that the price-income ratio continues to be overvalued by $15 \%$, while the overvaluation of the price-rent ratio is $8 \%$.

In the context of the far-reaching economic crisis in which Spain is immersed, our results will be useful for policymakers, who perform estimations of the pace at which the housing stock will reduce. In 2010, the number of new dwellings waiting to be sold amounted to 687,523 units; $47 \%$ of this stock is located in provinces close to the Mediterranean. In fact, $19.3 \%$ of this stock is concentrated in the three provinces of the Autonomous Community of Valencia (Alicante, Castellón, and Valencia), meaning a large part of the stock is housing aimed at second homes. Given this context, the Management Company for Assets from Bank Restructuring (SAREB) will manage the sale of 89,000 dwellings from financial entities nationalized by the Spanish governments in recent years. The average discount for these dwellings (with regard to the original market value) will be close to $55 \%$. Although this discount is great, the speed at which SAREB 
will be able to reduce housing stock will depend on the response of possible purchasers to prices and income. Our results provide little optimism regarding the pace of absorption induced by the purchases of Spanish residences. Firstly, because the rate of unemployment in 2014 was maintained at very high levels (around 25\%). Secondly, because disposable household income displayed negative rates, falling at a rate of $3.2 \%$ in 2012 . 


\section{Appendix A}

Exhibit A.1 | Summary of Variables

\begin{tabular}{|c|c|c|c|c|}
\hline Denomination & Content & Observations & Sample & Source \\
\hline Stockn & Real value of net housing stock & Millions of euros. Base year 2000 & 1975-2009 & $\begin{array}{l}\text { Fundación BBVA-IVIE (Mas } \\
\text { et al., } 2007 \text { and updates) }\end{array}$ \\
\hline Stockb & Real value of gross housing stock & Millions of euros. Base year 2000 & 1975-2009 & $\begin{array}{l}\text { Fundación BBVA-IVIE (Mas } \\
\text { et al., } 2007 \text { and updates) }\end{array}$ \\
\hline Housing prices & $\begin{array}{l}\text { Linked series of housing prices in Spain; 1975- } \\
1990 \text { data Prados de la Escosura (2003): 1990- } \\
2007 \text { data Fundación BBVA-IVIE (Jiménez et al., } \\
\text { 2009); 2007-2009 data INE }\end{array}$ & $\begin{array}{l}\text { Euros } / \mathrm{m}^{2} \text {. The link is performed } \\
\text { by guaranteeing the maintenance } \\
\text { of the annual rates of variation of } \\
\text { the different linked variables. }\end{array}$ & 1975-2009 & Authors' elaboration \\
\hline Real housing prices & Housing prices deflated by the CPI & Base year 2005 & 1975-2009 & Authors' elaboration \\
\hline Population & Total population in Spain & Thousands of persons & 1975-2009 & $\begin{array}{l}\text { Instituto Nacional de } \\
\text { Estadística (INE) }\end{array}$ \\
\hline Interest rates & Average interest rates of mortgage market & Averages of monthly data & 1975-2009 & Banco de España \\
\hline Real interest rates & Interest rates deflated by the CPI & Per unit basis & 1975-2009 & Authors' elaboration \\
\hline
\end{tabular}


Exhibit A.1 | (continued)

Summary of Variables

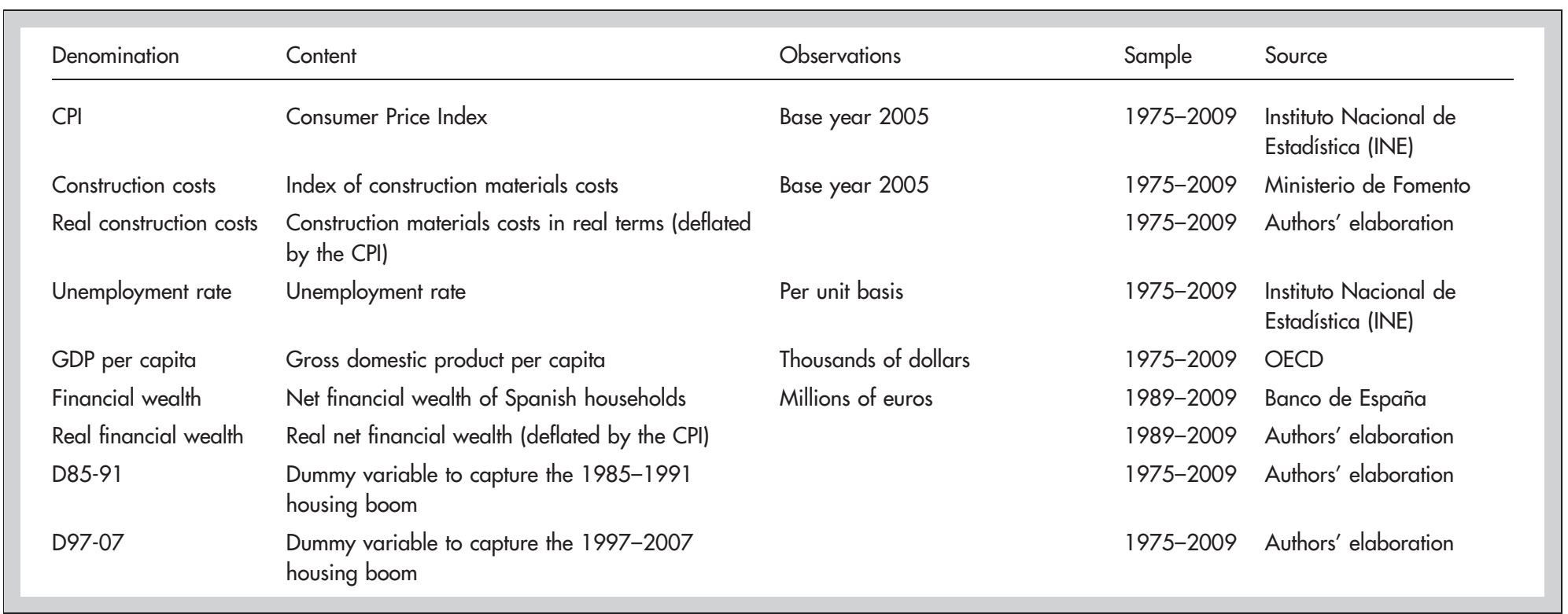


Appendix $B$

Unit Root and Cointegration Tests

Exhibit B.1 | Unit Root Tests

\begin{tabular}{|c|c|c|c|}
\hline Variable & ADF T\&I & ADF I & ADF \\
\hline Stockba & $\begin{array}{c}-2.091 \\
(0.535)\end{array}$ & $\begin{array}{c}-0.894 \\
(0.778)\end{array}$ & $\begin{array}{c}2.318 \\
(0.994)\end{array}$ \\
\hline Real housing prices ${ }^{a}$ & $\begin{array}{c}-2.500 \\
(0.325)\end{array}$ & $\begin{array}{c}-2.399 \\
(0.149)\end{array}$ & $\begin{array}{c}-1.419 \\
(0.142)\end{array}$ \\
\hline \multirow[t]{2}{*}{ Population $^{a}$} & -3.102 & -0.855 & 1.473 \\
\hline & $(0.139)$ & (0.793) & $(0.963)$ \\
\hline Real interest rates & $\begin{array}{c}-1.842 \\
(0.663)\end{array}$ & $\begin{array}{c}-1.944 \\
(0.309)\end{array}$ & $\begin{array}{r}-1.095 \\
(0.242)\end{array}$ \\
\hline Real construction costs ${ }^{a}$ & $\begin{array}{c}-0.415 \\
(0.983)\end{array}$ & $\begin{array}{c}-2.008 \\
(0.282)\end{array}$ & $\begin{array}{r}-1.572 \\
(0.107)\end{array}$ \\
\hline Unemployment rate & $\begin{array}{r}-0.106 \\
(0.640)\end{array}$ & $\begin{array}{c}-2.498 \\
(0.125)\end{array}$ & $\begin{array}{r}-2.673 \\
(0.253)\end{array}$ \\
\hline GDP per capita ${ }^{a}$ & $\begin{array}{r}-1.746 \\
(0.713)\end{array}$ & $\begin{array}{c}-2.157 \\
(0.222)\end{array}$ & $\begin{array}{r}1.430 \\
(0.959)\end{array}$ \\
\hline Real financial wealtha & $\begin{array}{c}-0.929 \\
(0.931)\end{array}$ & $\begin{array}{c}-2.334 \\
(0.172)\end{array}$ & $\begin{array}{c}0.727 \\
(0.863)\end{array}$ \\
\hline
\end{tabular}


Exhibit B.2 | Cointegration Tests

\begin{tabular}{llllll}
$\begin{array}{l}\text { Endogenous } \\
\text { Variables }\end{array}$ & Exogenous Variables & $\begin{array}{l}\text { Phillips- } \\
\text { Ouliaris }\end{array}$ & $\begin{array}{l}\text { Engle and } \\
\text { Granger }\end{array}$ & Hansen & $\begin{array}{l}\text { Nonlinear Error } \\
\text { Correction }\end{array}$ \\
\hline Stockb & $\begin{array}{l}\text { Population, real } \\
\text { interest rates, real } \\
\text { construction costs, } \\
\text { unemployment rate } \\
\text { and GDP per } \\
\text { capita. }\end{array}$ & 0.052 & 0.045 & $>0.200$ & 0.814 \\
Stockb & & 0.008 & $>0.200$ & 0.125 \\
$\begin{array}{l}\text { Population, real housing prices } \\
\text { interest rates, real } \\
\text { construction costs, } \\
\text { unemployment rate, } \\
\text { GDP per capita and }\end{array}$ & 0.230 & 0.247 & 0.019 & 0.457 \\
Real housing prices & 0.025 & 0.022 & 0.152 & 0.842 \\
\hline
\end{tabular}

Notes: In the Hansen cointegration test (Hansen, 1992), the null hypothesis is cointegration, while in the Phillips-Ouliaris test (Phillips and Ouliaris, 1998) and in the Engle-Granger test (Engle and Granger, 1987) it is non-cointegration. In the nonlinear error correction test (Teräsvirta, 1994), the null hypothesis is linear error correction.

\section{Endnotes}

${ }^{1}$ Consequently, the volume of resources allocated to housing construction has been enormous. In 2005, for example, the weight of the residential investment sector in GDP was $8.9 \%$. This figure is slightly lower than the level of Ireland (13.9\%) but greatly exceeds the $3.9 \%$ of the U.K., the $4.6 \%$ of France or the $5.6 \%$ of Germany. Naturally, a lesser weight of residential investment does not avoid the existence of property booms, although if they were to exist their effects upon the real economy would be much lower (Conefrey and Gerald, 2010).

2 This figure is slightly lower than the level of Ireland (13.9\%) but greatly exceeds the $3.9 \%$ of the U.K., the $4.6 \%$ of France or the $5.6 \%$ of Germany.

${ }^{3}$ In Ireland, this doubled in a single year, from $6.1 \%$ in 2008 to $12.2 \%$ in 2009, while in France and the U.K. the increases in the unemployment rate between 2008 and 2012 were approximately 2.5 percentage points.

${ }^{4}$ In 2008, it occupied the eighth position worldwide in terms of GDP. However, the sharp deterioration in the balance sheets of banks and savings banks, as a consequence of their exposure to the property boom, obliged the Spanish government to request a banking rescue package of up to 100,000 million euros from the European Union in 2012.

5 Among others, Servicio de Estudios del BBVA (2002), Ayuso and Restoy (2003), García-Montalvo (2003), Martínez and Maza (2003), and The Economist (2003a, b).

${ }^{6}$ Data compiled by the Instituto Valenciano de Investigaciones Económicas (IVIE) (see Mas Ivars et al., 2007). 
7 The increase in the number of units in the 1970s, 1980s, and 1990s was 4.3, 2.4, and 3.3 million, respectively.

8 A good example of these differences can be found in Lee, Schmidt-Dengler, Felderer, and Helmenste (2001) for Austria; Lum (2002) for Singapore or Carreras i Solanas, Mascarilla-i-Miró, and Yegorov (2004) for Spain.

9 The formulation is equally valid if it is considered that the variables involved in the analysis are transformed logarithmically (e.g., Meen, 2002; Andrews, Caldera Sánchez, and Johansson, 2011). Obviously, what is indeed modified is the interpretation of the parameters.

10 The user cost of capital is a more complex measurement than the interest rate, since it considers, in addition to the interest rate, other variables such as property taxes, maintenance costs, and the rate of depreciation. In fact, in the empirical application, tests were performed employing approximation of the user cost of capital proposed by Poterba (1992). However, this measurement was not statistically significant, and consequently we opted to approximate the user cost of capital by a measurement of interest rates.

11 For Spain, there are no hedonic long run price series that capture the quality of dwellings (proximity to public services, quality of construction, average air quality, noise level etc.). Accordingly, and as in Sawaya (2005), prices are expressed in euros $/ \mathrm{m}^{2}$ (see Exhibit A.1 of Appendix A). Nevertheless, for the 1993-1997 period, Bover and Velilla (2002) estimate that the response of price per square meter to dwelling size hardly varies when the equation includes other exogenous variables such as the presence of air conditioning, swimming pool, garden or sports facilities $(0.78$ vs. 0.74 when the characteristics of the dwelling are included). Bearing in mind these results, we do not believe that the results of the estimations would be very different if dwelling prices adjusted by quality were available.

12 This model is available upon request.

13 The information corresponding to this variable is compiled by the Banco de España and reflects the net value of financial assets (cash, shares, loans, etc.) in the hands of Spanish households.

14 The number of annual marriages was also considered, as a measure of the creation of households, as it was assumed that the creation of households potentially generates a need for housing. This variable was not included in the study because it was not statistically significant.

15 Other possibilities were considered, such as GDP or private consumption. However, the variable that produced the best results was GDP per capita.

${ }^{16}$ Other options were also contemplated, namely employment and unemployment. The most satisfactory result was that obtained using the unemployment rate.

17 As is habitual in the literature, the logarithmic formulation does not transform the variables expressed into rates such as the unemployment rate or interest rates.

18 Models with variables in levels were also estimated; these provided good results and are available upon request.

19 Production costs are lagged because they were not contemporaneously significant. This is possibly due to the very nature of the construction industry, where lags are common between changes in costs and in construction activity (Andrews, Caldera Sánchez, and Johansson, 2011). 
20 As indicated in the model, stock is expressed in gross terms. Complementarily, estimations were performed with stock in net terms. Results are in full accordance with those obtained when employing gross stock. This model is available upon request.

21 The results of the unit root tests performed (see Exhibit B.1 of Appendix B) show clear evidence in favor of the non-stationary character of the processes generating the variables considered in the study. This characteristic conditions not only the econometric analysis but also the interpretation of the model summarized in equations (7) and (8). In other words, verification must be made of the possible existence of an observed long-term equilibrium relationship between prices and housing stock observed and their determinants.

22 Cointegration tests were performed between determinants of the reduced form equations and the lags of stock and prices observed. These tests confirmed, at least for the model estimated with the 1975-2009 sample, evidence of a possible long-term equilibrium relationship (see Exhibit B.2 of Appendix B). The possible existence of a nonlinear error correction model was also contemplated, but the linearity test performed did not permit the rejection of the hypothesis of linearity at the usual levels of significance (see Exhibit B.2 in Appendix B)

23 When a measure of wealth is included, the evidence of the existence of a long-run equilibrium relationship diminishes notably (see Exhibit B.2 in Appendix B). It is possible that this result is not unconnected to the small sample size.

${ }^{24}$ International experience indicates that the most frequent adjustment range oscillates between four and six years, although the records are held by Switzerland and Japan, with 10 years (the former at the end of the 1980s and the latter in the 1990s) (Kelly, 2007).

\section{References}

Agnello, L. and L. Schuknecht. Booms and Busts in Housing Markets: Determinants and Implications. Journal of Housing Economics, 2011, 20, 171-90.

Akin, O., J. García-Montalvo, J. García-Villar, J.L. Peydró, and J.M. Raya. The Real Estate and Credit Bubble: Evidence from Spain. SERIEs, 2014, 5, 223-43.

André, C. A Bird's Eye View of OECD Housing Markets. OECD Economics Department, Working Papers, 2010, 746.

Andrews, D. and A. Caldera Sánchez. To Move or Not to Move: What Drives Residential Mobility in the OECD? OECD Economics Department, Working Papers, 2011, 846.

Andrews, D., A. Caldera Sánchez, and A. Johansson. Housing Markets and Structural Policies in OECD Countries. OECD Economics Department, Working Papers, 2011, 836.

Ayuso, J. and F. Restoy. House Prices and Rents: An Equilibrium Asset Pricing Approach. Servicio de Estudios del Banco de España, Documento de Trabajo, 2003, 0304.

Ayuso, J., J. Martinez, L. Maza, and F. Restoy. House Prices in Spain. Economic Bulletin, Banco de Espana, 2003, October, 69-74.

Ball, M., G. Meen, and C. Nygaard. Housing Supply Price Elasticities Revisited: Evidence from International, National, Local and Company Data. Journal of Housing Economics, 2010, 19, 255-68.

Banco de España. Boletín Económico. September, 2002.

Barakova, I., P.S. Calem, and S.M. Wachter. Borrowing Constraints during the Housing Bubble. Journal of Housing Economics, 2014, 24, 4-20. 
Barrios, J.A. and J.E. Rodríguez. Un Modelo Logit Multinomial Mixto de Tenencia de Vivienda. Revista de Economía Aplicada, 2005, 13:38, 5-27.

Blackley, D.M. The Long-run Elasticity of New Housing Supply in the United States: Empirical Evidence for 1950 to 1994. Journal of Real Estate Finance and Economics, 1999, 18:1, 25-42.

Bover, O. and P. Velilla. Hedonic House Prices Without Characteristics: The Case of New Multiunit Housing. CEPR Discussion Paper 3161, 2002.

Bracke, P. How Long Do Housing Cycles Last? A Duration Analysis for 19 OECD Countries. Journal of Housing Economics, 2013, 22, 213-30.

Caldera Sánchez, A. and A. Johansson. The Price Responsiveness of Housing Supply in OECD Countries. Journal of Housing Economics, 2013, 22, 231-49.

Carreras-i-Solanas, M., O. Mascarilla-i-Miró, and Y. Yegorov. The Evolution and the Relationship of House Prices and Rents in Barcelona, 1970-2002. European Journal of Housing Policy, 2004, 4:1, 19-56.

Central Statistics Office. Residential Property Price Index. http://www.cso.ie/en/ releasesandpublications/er/rppi/residentialpropertypriceindexapril2014/. 2014.

Comisión Nacional de la Competencia. Problemas de Competencia en el Mercado de Suelo en España. Documento de discussion, 2014.

Conefrey, T. and G.F. Gerald. Managing Housing Bubbles in Regional Economies Under EMU: Ireland and Spain. National Institute Economic Review, 2010, 211:1, 211-99.

DiPasquale, D. and W.C. Wheaton. Housing Market Dynamics and the Future of Housing Prices. Journal of Urban Economics, 1994, 35:1, 1-27.

Duca, J.V., J. Muellbauer, and A. Murphy. Housing Markets and the Financial Crisis of 2007-2009: Lessons for the Future. Journal of Financial Stability, 2010, 6:4, 203-17.

Engle, R.F. and C.W.J. Granger. Co-integration and Error Correction: Representation, Estimation, and Testing. Econometrica, 1987, 55, 251-76.

Fernández-Kranz, D. and M.T. Hon. A Cross-section Analysis of the Income Elasticity of Housing Demand in Spain: Is There a Real Estate Bubble? Journal of Real Estate Finance and Economics, 2006, 32, 449-70.

Frappa, S. and J.S. Mésonnier. The Housing Price Boom of the Late 1990s: Did Inflation Targeting Matter? Journal of Financial Stability, 2010, 6:4, 243-54.

García-Montalvo, J. La Vivienda en España: Desgravaciones, Burbujas y Otras Historias. Perspectivas del Sistema Financiero, 2003, 78, 1-43.

- Perspectivas del Precio de la Vivienda en España. Cuadernos de Información Económica, 2012, 227, 49-59.

- The Spanish Housing Market: Is the Adjustment Over? Spanish Economic and Financial Outlook, 2013, 5, 57-68.

García-Montalvo, J. and J.M. Raya. What is the Right Price of Spanish Residential Real Estate? Spanish Economic and Financial Outlook, 2012, 1:3, 22-8.

Girouard, N., M. Kennedy, P. Van den Noord, and C. André. Recent House Price Developments: The Role of Fundamentals. OECD Economics Department, Working Papers, 2006, 475.

González, L and F. Ortega. Immigration and Housing Booms: Evidence from Spain. Journal of Regional Science, 2013, 53, 37-59.

Gruppe, M. and C. Lange. Spain and the European Sovereign Debt Crisis. European Journal of Political Economy, 2014, 32, S3-S8. 
Hansen, B. Tests for Parameter Instability in Regressions with I(1) Processes. Journal of Business and Economic Statistics, 1992, 10, 321-35.

Hay, C. Good Inflation, Bad Inflation: The Housing Boom, Economic Growth and the Disaggregation of Inflationary Preferences in the U.K. and Ireland. British Journal of Politics \& International Relations, 2009, 11:3, 461-78.

International Monetary Fund (IMF). Spain: Selected Issues. IMF Country Report, 2009, $09 / 129$.

Instituto Nacional de Estadística (INE). Índice de Precios de la Vivienda. http:// www.ine.es $/ \mathrm{jaxiBD} /$ menu.do? $\mathrm{L}=0$ \&divi $=\mathrm{IPV} \&$ his $=1 \&$ type $=\mathrm{db} .2014$.

Kang, H-H. and S-B. Liu. The Impact of the 2008 Financial Crisis on Housing Prices in China and Taiwan: A quantile Regression Analysis. Economic Modelling, 2014, 42, 35662.

Kelly, M. On the Likely Extent of Falls in Irish House Prices. UCD Centre for Economic Research Working Paper, WP07/01, 2007.

Kenny, J. Asymmetric Adjustment Costs and the Dynamics of Housing Supply. Economic Modeling, 2003, 20, 1097-1111.

Knudsen, D. Residential Investment and House Prices in Denmark. Economic Modeling, 1994, 11:2, 201-14.

Lee, G.S., P. Schmidt-Dengler, B. Felderer, and C. Helmenstein. Austrian Demography and Housing Demand: Is There a Connection? Empirica, 2001, 259-76.

Lum, S.K. Market Fundamentals, Public Policy and Private Gain: House Price Dynamics in Singapore. Journal of Property Research, 2002, 19:2, 121-43.

Malpezzi, S. and D. Maclennan. The Long-run Price Elasticity of Supply of New Residential Construction in the United States and the United Kingdom. Journal of Housing Economics, 2001, 278-306.

Mas Ivars, M., F. Pérez García, E. Uriel Jiménez, V. Cucarella Tormo, J.C. Robledo Domínguez, and L. Serrano Martínez. El Stock y los Servicios Del Capital en España y su Distribución Territorial (1964-2003): Nueva Metodología, Madrid: Fundación BBVA, 2007.

Mártinez, M.T. The Spanish Financial System: Facing up to the Real Estate Crisis and Credit Crunch. International Journal of Housing Policy, 2008, 8:2, 181-196.

Martínez, J. and L.A. Maza. Análisis del Precio de la Vivienda en España. Servicio de Estudios del Banco de España. Documento de Trabajo, 0307, 2003.

Mayer, C.J. and C.T. Somerville. Residential Construction: Using the Urban Growth Model to Estimate Housing Supply. Journal of Urban Economics, 2000, 48, 85-109.

Meen, G. The Time-Series Behavior of House Prices: A Transatlantic Divide? Journal of Housing Economics, 2002, 11, 1-23.

- Ten New Propositions in U.K. Housing Macroeconomics: An Overview of the First Years of the Century. Urban Studies, 2008, 45:13, 2759-81.

Ministerio de Fomento. Informe Sobre el Stock de Vivienda Nueva 2011. http:// www.fomento.gob.es/NR/rdonlyres/3525DAE3-79D1-469A-B7BC-5DFAF028D7DC/ 112289/SVN_11.pdf. 2012a.

Ministerio de Fomento. Estimación del Parque de Viviendas. http://www.fomento.gob.es/ BE2/?nivel $=2 \&$ orden $=33000000.2012$ b.

Moro, B. Lessons from the European Economic and Financial Great Crisis: A Survey. European Journal of Political Economy, 2014, 32, S9-S24. 
Naredo, J.M. La Burbuja Inmobiliaria-financiera en la Coyuntura Económica Reciente (1985-1995). Madrid, Siglo XXI, 1996.

Naredo, J.M. Perspectivas de la Vivienda. Información Comercial Española, 2004, 815, 143-54.

Naredo, J.M., O. Carpintero, and C. Marcos. Patrimonio en Vivienda y Ahorro de Los Hogares en el Final del Ciclo Inmobiliario. Cuadernos de Información Económica, 212, September-October, 2009.

Organisation for Economic Co-operation and Development (OECD). Economic Survey of Spain 2004. 2004.

—. Economic Survey of Spain 2005. 2005.

—. Economic Survey of Spain 2007. 2007.

—. Economic Policy Reforms 2011: Housing and the Economy, Policies for Renovation. 2011.

Phillips, P.C.B. and S. Oualiaris. Testing for Cointegration using Principal Component Methods. Economics Dynamic and Control, 1998, 12, 205-30.

Poterba, J. Tax Subsidies to Owner-Occupied Housing: An Asset-Market Approach. Quarterly Journal of Economics, 1984, 99:4, 729-52.

- Taxation and Housing: Old Questions, New Answers. American Economic Review, 1992, 82:2, 237-42.

Prados de la Escosura, L. El Progreso Económico de España (1850-2000). Madrid: Fundación BBVA, 2003.

Riddel, M. Housing Market Disequilibrium: An Examination of Housing Market Price and Stock Dynamics 1967-1998. Journal of Housing Economics, 2004, 13, 120-35.

Sawaya Neto, M.S. Analysis of the Determinants of New Housing Investment in Spain. Housing Theory and Society, 2005, 22:1, 18-31.

Servicio de Estudios del BBVA. Situación Inmobiliaria, December, 2002.

Steiner, E. Estimating a Stock-flow Model for the Swiss Housing Market. Swiss Society of Economics and Statistics, 2010, 146:3, 601-27.

Tafunell, X. Urbanización y vivienda. In Estadísticas Históricas de España. C. Carreras and X. Tafunell (eds.). Volume 1. Madrid, Fundación BBVA, 2005.

Taltavull de la Paz, P. La Oferta de Viviendas y el Mercado Inmobiliario en España. Papeles de Economía Española, 2006, 109, 156-81.

Teräsvirta, T. Specification, Estimation, and Evaluation of Smooth Transition Autoregressive Models. Journal of the American Statistical Association, 1994, 89, $208-$ 18.

The Economist. The Seven Deadly Sins. 11/27/2003. 2003a.

- Shaky Foundations: The Higher House Prices Climb, the More they are Likely to Fall. 11/27/2003, 2003b.

Topel, R. and S. Rosen. Housing Investment in the United States. Journal of Political Economy, 1988, 96:4, 718-40.

Uriel Jiménez, U., C. Albert Pérez, E. Banages Candau, V. Cucarella Tormo, H. García Peris, and R. Aragón Rodríguez. El Stock de Capital en Vivienda en España y su Distribución Territorial (1990-2007). Madrid: Fundación BBVA, 2009. 
Wang, M. Bubble-like Housing Boom-Bust Cycles: Evidence from the Predictive Power of Households' Expectations. Quarterly Review of Economics and Finance, 2014, 54, 2 16.

Wang, H. and K. Wang. What is Unique about Chinese Real Estate Markets? Journal of Real Estate Research, 2012, 3, 275-89.

Wang, S., S.H. Chan, and B. Xu. The Estimation and Determinants of the Price Elasticity of Housing Supply: Evidence from China. Journal of Real Estate Research, 2012, 3, 31144.

Wigren, R. and M. Wilhelmsson. Housing Stock and Price Adjustments in 12 West European Countries between 1976 and 1999. Housing Theory and Society, 2007, 24:2, $133-54$.

The authors would like to thank the editor and the three anonymous referees for their insightful comments, which have clearly improved the initial version of the manuscript. José Félix Sanz-Sanz acknowledges the financial support provided by research project ECO2012-35572. María Arrazola and José de Hevia acknowledge the financial support provided by FUNCAS.

María Arrazola, Universidad Rey Juan Carlos, Paseo de los Artilleros s/n, 28032 Madrid, Spain or maria.arrazola@urjc.es.

José de Hevia, Universidad Rey Juan Carlos, Paseo de los Artilleros s/n, 28032 Madrid, Spain or jose.dehevia@urjc.es.

Desiderio Romero-Jordán, Universidad Rey Juan Carlos, Paseo de los Artilleros s/n, 28032 Madrid, Spain or desiderio.romero@urjc.es.

José Félix Sanz-Sanz, Universidad Complutense de Madrid, Pozuelo de Alarcón, 28223 Madrid, Spain or jfelizs@ccee.ucm.es. 